\title{
$\mathrm{UiO}$ : Det juridiske fakultet
}

\section{Tolkning av enkeltvedtak}

Hvordan fastlegges de rettigheter og plikter som følger av et enkeltvedtak?

Kandidatnummer: 657

Leveringsfrist: 25. november 2018

Antall ord: 17992 


\section{Innholdsfortegnelse}

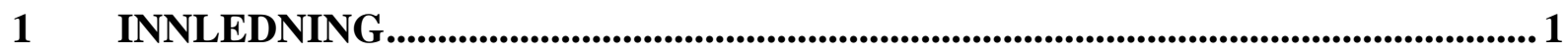

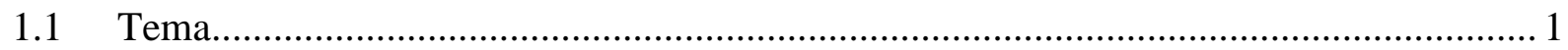

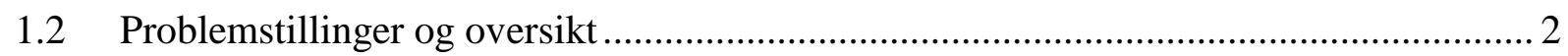

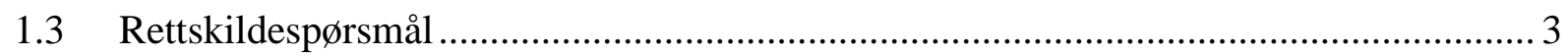

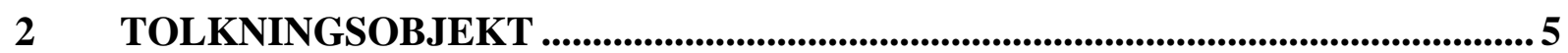

3 DOMSTOLENES KOMPETANSE OG SAKSTYPER .........................................8

3.1 Domstolenes kompetanse til å tolke enkeltvedtak ................................................... 8

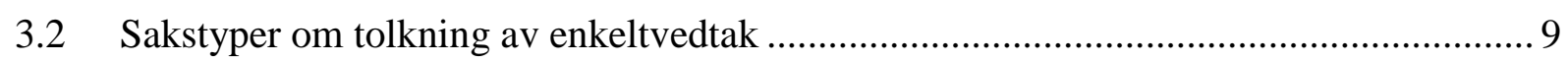

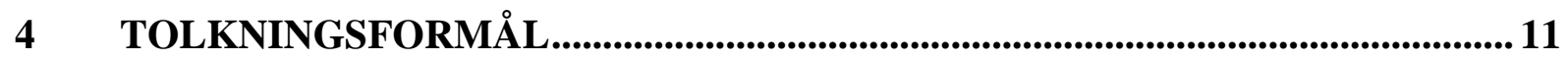

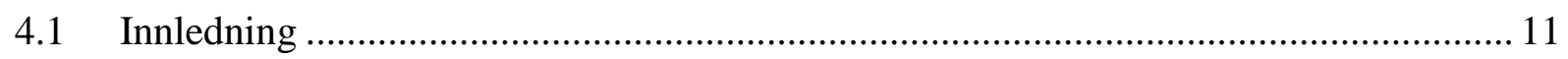

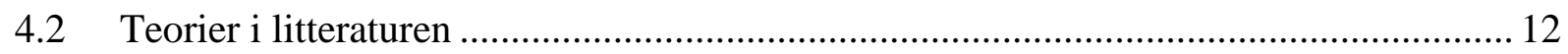

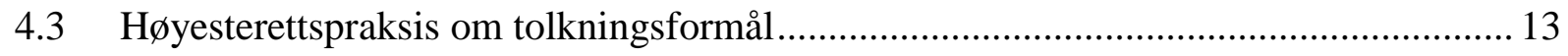

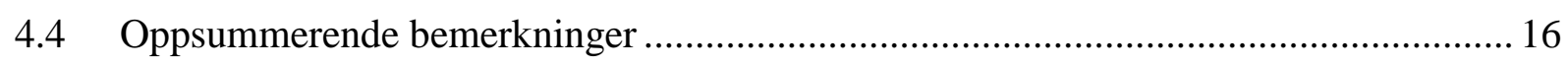

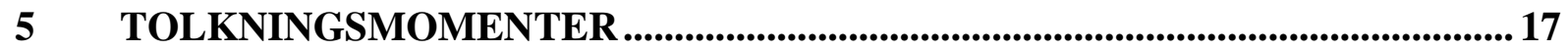

5.1 Tolkningsprosessen - en avveining av tolkningsmomenter ..................................... 17

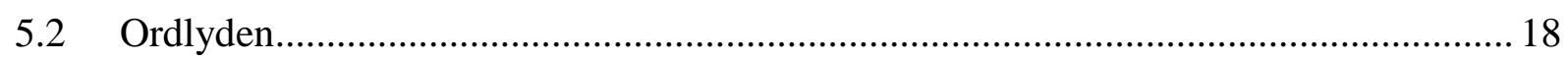

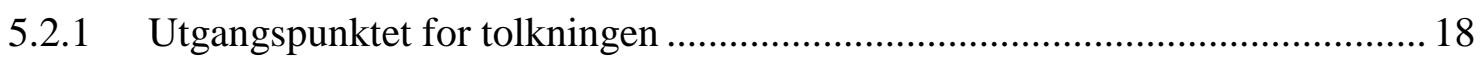

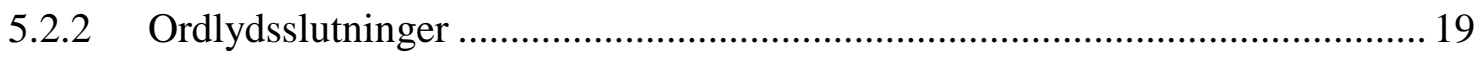

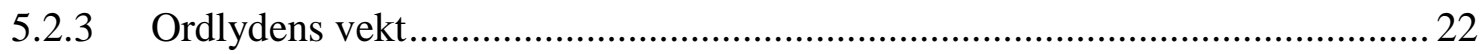

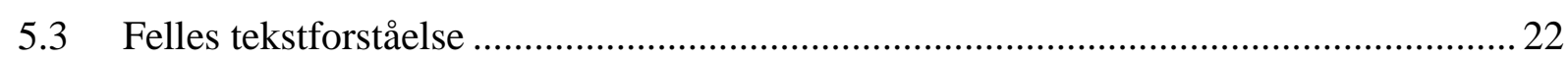

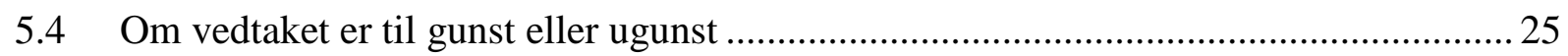

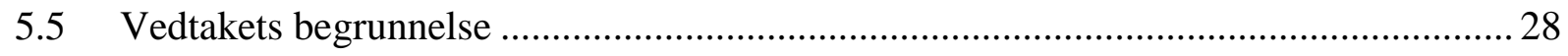

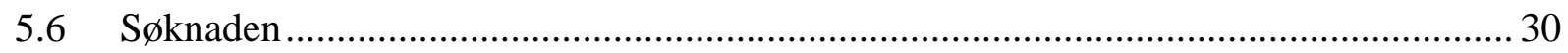

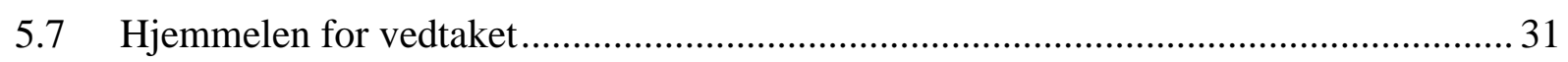

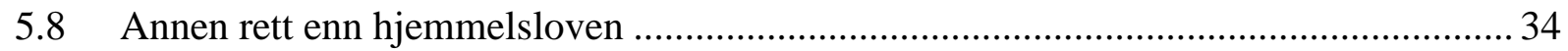

5.9 Vedtakets forarbeider, forhandlinger og annen forhistorie ....................................... 35

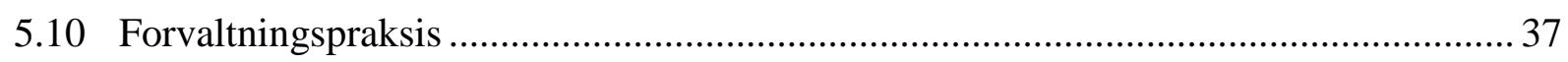

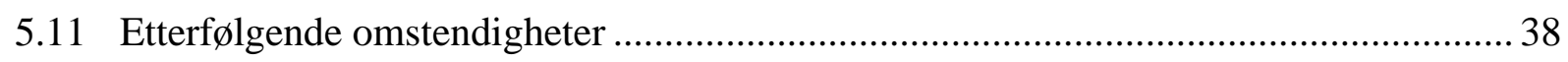

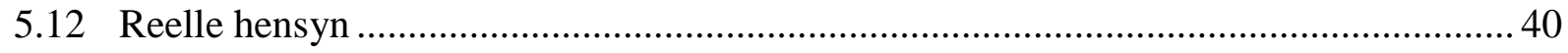

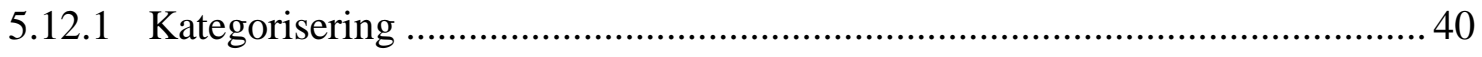

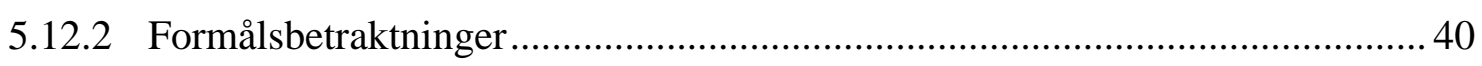

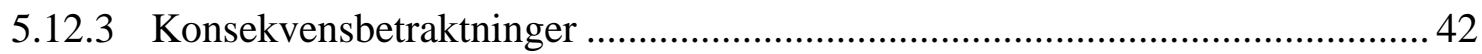




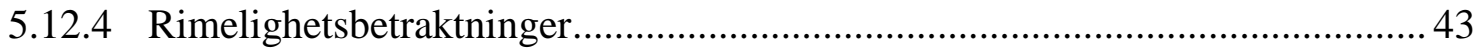

5.13 Særskilte momenter ved tolkning av klagevedtak og omgjøringsvedtak ..................... 44

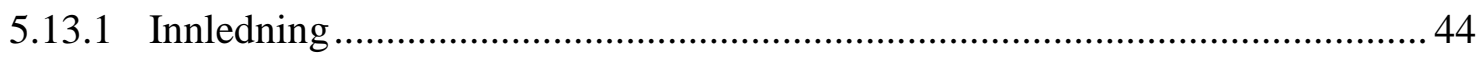

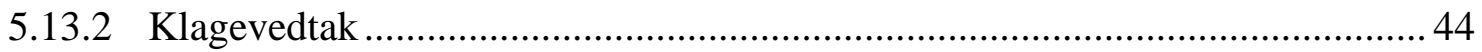

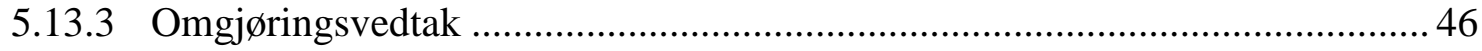

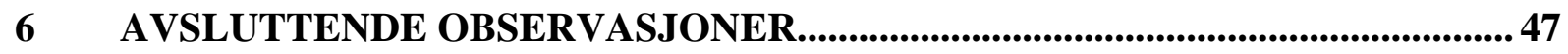

KILDELISTE ................................................................................................................................ 49 


\section{$1 \quad$ Innledning}

\section{$1.1 \quad$ Tema}

Denne masteroppgaven handler om tolkning av enkeltvedtak. Med dette mener jeg fremgangsmåten for å fastlegge innholdet av de enkeltvedtak som forvaltningen har fattet.

Daglig fattes enkeltvedtak i staten, fylkeskommunene og kommunene. De samme tolkningsproblemer kan oppstå her som i andre rettslig bindende tekster. Foreldrene som mottar et barnevernsvedtak kan få problemer med å forstå hvilke tiltak som skal iverksettes. Skattyteren kan få problemer med å forstå hvor mye han skal betale i skatt. Oljeselskapet kan få problemer med å forstå de omfattende vilkårene som hører med til en utvinningstillatelse. Alle disse vedtakene må tolkes for å klarlegge hvilke rettigheter og plikter som følger av dem. Ofte byr ikke forståelsen av vedtakene på problemer i det hele tatt, mens andre ganger kan den by på adskillig tvil.

I juridisk litteratur er det skrevet lite om tolkning av enkeltvedtak, til tross for at tolkningen kan ha stor betydning for både den private part og forvaltningen. Det er bare skrevet noen få sider direkte om temaet. ${ }^{1}$ I tillegg har enkelte forfattere indirekte berørt temaet. ${ }^{2}$ Til sammenligning er det skrevet mye om tolkning av andre rettslig bindende tekster, som lover, avtaler, traktater, testamenter og dommer. Det er derfor et behov for en fremstilling av tolkning av enkeltvedtak i forvaltningsretten. Etter hva jeg kjenner til er mitt bidrag den mest dyptpløyende behandlingen av temaet så langt.

Med «enkeltvedtak» legger jeg til grunn definisjonen i forvaltningsloven $\S 2$ bokstav b, som igjen bygger på definisjonen av vedtak i fvl. $\S 2$ bokstav a. Enkelte lover, som for eksempel skatteforvaltningsloven $\S 1-2$ bokstav d, har egne definisjoner av enkeltvedtak. Det kan være noe ulikt hva som faller innenfor og utenfor slike særskilte definisjoner sammenlignet med forvaltningslovens definisjon, men forskjellene har neppe betydning for hvordan de ulike enkeltvedtakene skal tolkes. Det sentrale innholdet i alle legaldefinisjonene er uansett at enkeltvedtak er en avgjørelse truffet under utøving av offentlig myndighet som gjelder rettigheter og plikter for en eller flere bestemte personer.

\footnotetext{
${ }^{1}$ Knoph (1927) s. 14-19, Castberg (1955) s. 133-137 og 148-152, Huser (1983) s. 410, 434-435 og 479, Boe (2010) s. 263-264, Hagstrøm (2011) s. 691, Boe og Woxholth (2013) s. 88-89 og Hopsnes (2017) s. 271-275.

${ }^{2}$ Bernt (1981) s. 109-112, Bernt og Rasmussen (2010) s. 334, Aanerud (2017) s. 111-172 og Eckhoff og Smith (2018) s. 428.
} 


\subsection{Problemstillinger og oversikt}

Hovedproblemstillingen er hvordan de rettigheter og plikter som følger av et enkeltvedtak fastlegges.

Rettighetene og pliktene som blir fastlagt vil gjelde for den som er part i vedtaket. Hvem som er «part» er definert i fvl. $\S 2$ bokstav e som den avgjørelsen «retter seg mot» eller som saken «ellers direkte gjelder». En rett eller plikt for parten vil motsvares av en plikt eller rett for staten, en fylkeskommune eller en kommune.

Hovedproblemstillingen kan deles opp i to underproblemstillinger. Den første problemstillingen er om det gjelder et bestemt formål ved tolkningen, og i så fall om det går ut på en subjektiv eller objektiv tolkning. Dette blir i juridisk litteratur ofte omtalt som et spørsmål om «tolkningsstandard», «tolkningstema», «tolkningsteori» eller «tolkningsprinsipp». Jeg synes uttrykket «tolkningsformål» er mer presist, fordi det viser direkte til det som er spørsmålet. Dette behandles i punkt 4 .

Den andre problemstillingen er hvilke tolkningsmomenter som er relevante og hvilken vekt disse momentene har i avveiningen mot andre tolkningsmomenter. Ettersom Høyesterett i større grad fokuserer på konkrete tolkningsmomenter enn hvilket tolkningsformål som gjelder, vil underproblemstillingen om tolkningsmomenter vies klart størst plass i oppgaven. Tolkningsmomentene behandles i punkt 5 .

Før jeg kommer til disse to underproblemstillingene, vil jeg avklare noen andre spørsmål av betydning for tolkning av enkeltvedtak. Først vil jeg i punkt 1.3 ta opp noen særegne rettskildespørsmål for tolkning av enkeltvedtak. Deretter vil jeg i punkt 2 gå nærmere inn på tolkningsobjektet, altså hva som skal tolkes. Etter dette vil jeg i punkt 3 si noe om domstolenes kompetanse til å tolke enkeltvedtak og hvilke sakstyper hvor tolkning av enkeltvedtak kommer opp for domstolene. Dette fordi rettspraksis er en sentral kilde til hvilket tolkningsformål og hvilke tolkningsmomenter som gjelder.

Samlet sett vil innholdet i disse punktene vise hvordan rettigheter og plikter som følger av et enkeltvedtak fastlegges. I punkt 6 kommer jeg med noen avsluttende observasjoner. 


\section{$1.3 \quad$ Rettskildespørsmål}

Ettersom oppgaven handler om å analysere hvordan innholdet av et enkeltvedtak fastlegges, skiller den seg fra teori som forsøker å fastlegge gjeldende materiell rett. Temaet reiser derfor noen metodiske spørsmål som har fellestrekk med teori om rettskildelære og teori om tolkning av andre rettslig bindende tekster.

Et første spørsmål er hvilket kildemateriale som kan gi grunnlag for tolkningsnormer. Det er sjeldent at tolkningsnormer følger av lover eller andre formelle vedtak, og det er heller ikke tilfellet for enkeltvedtak. Lovgivningen kan være et tolkningsmoment ved fastleggingen av et enkeltvedtaks innhold, men den gir ikke uttrykk for tolkningsnormer. Det samme gjelder lovforarbeider.

Høyesterettspraksis får derfor en særlig fremtredende posisjon som kilde til tolkningsnormer, ${ }^{3}$ men også andre domstolers praksis, forvaltningspraksis, uttalelser fra Sivilombudsmannen, reelle hensyn og juridisk teori kan spille en rolle. I tillegg kan utenlandsk teori være relevant, men her har jeg har kun funnet én side i dansk forvaltningsrett. ${ }^{4}$

Noen av kildene gjelder tolkningen av individualiserte vedtak (en tidligere betegnelse var «forvaltningsakt» ${ }^{5}$ ) fra før forvaltningsloven av 1967 innførte termen «enkeltvedtak», men disse kildene er fortsatt relevante. Tolkningsnormene er begrunnet i de hensyn som gjør seg gjeldende ved at offentlige myndigheter fatter vedtak overfor den enkelte, og de hensyn gjør seg gjeldende uansett hva lovgivningen kaller vedtakene.

Et annet spørsmål gjelder bruken av høyesterettspraksis om tolkningsspørsmål. Å anvende høyesterettspraksis som kilde til tolkningsnormer er noe annet enn å anvende det som kilde til gjeldende materiell rett. ${ }^{6}$ Eng har reist spørsmål om prejudikatlæren kan anvendes for å utlede rettskildenormer,$^{7}$ og dette spørsmålet reiser seg også for tolkningsnormer. ${ }^{8}$ Eckhoff reserverer seg for å anvende prejudikatlæren på såkalte prinsipputtalelser fra Høyesterett om rettskildenormer, og antyder at det er argumentasjonsmønstre over tid som er avgjørende. ${ }^{9}$ Det samme

\footnotetext{
${ }^{3}$ Høgberg (2006) s. 84 påpeker også dette i sin fremstilling av kontraktstolkning.

${ }^{4}$ Andersen (1930) s. 257-258.

${ }^{5}$ Castberg (1955) s. 138 definerer «forvaltningsakt» som offentlige utsagn om rett og plikt i det «individuelle tilfelle».

${ }^{6}$ Høgberg (2006) s. 84.

${ }^{7}$ Eng (1997) s. 21-44.

${ }^{8}$ Høgberg (2006) s. 84-85.

${ }^{9}$ Eckhoff (2001) s. 21.
} 
gjør Høgberg for tolkningsnormer, ettersom han mener tolkningsspørsmål har likhetstrekk med rettskildespørsmål. ${ }^{10}$ Dette betyr at det i juridisk teori er tatt til orde for at prinsipputtalelser fra Høyesterett ikke har den samme vekt for slutninger om rettskildenormer og tolkningsnormer som ved fastleggelsen av gjeldende materiell rett.

Selv om argumentasjonsmønstre over tid må ha større vekt enn en enkelt prinsipputtalelse om enten rettskildenormer eller tolkningsnormer, vil en prinsipputtalelse likevel kunne si noe om Høyesteretts tolkningsmetode. Når tolkningen av et enkeltvedtak kan avgjøres av Høyesterett i siste instans, jfr. Grunnloven $\S 88$, tilsier det også at man retter seg etter Høyesteretts erklærte tolkningsmetode. Høyesterett selv viser ofte til, og følger, sine egne prinsipputtalelser om både rettskildenormer og tolkningsnormer. HR-2016-2017-A er et av mange eksempler på dette. I avsnitt 50 viste Høyesterett uttrykkelig til én tidligere doms prinsipputtalelse om at forvaltningspraksis er en rettskilde og la dette til grunn. Rt-2004-957 (PGS) er et annet eksempel. I avsnitt 40 viste Høyesterett uttrykkelig til tidligere prinsipputtalelser om tolkning av skatteavtaler (traktater) og la dette til grunn.

I denne oppgaven vil derfor både prinsipputtalelser og de større argumentasjonsmønstre fra Høyesterett anvendes som kilde til tolkningsnormer, men argumentasjonsmønstrene over tid vil ha størst vekt.

Det er likevel viktig å huske på at de fleste enkeltvedtak aldri kommer opp for domstolene - og blant dem som kommer opp, er det få som gjelder tolkningen av vedtakene. Dette betyr at forvaltningens egen tolkningspraksis har stor faktisk betydning for den som er part i et enkeltvedtak. I stor grad er likevel mitt perspektiv hvordan domstolene tolker enkeltvedtak. For det første har høyesterettspraksis større vekt enn forvaltningspraksis. For det andre er det ikke mulig å få gjennomført omfattende analyser av forvaltningens tolkningspraksis - dels fordi det nødvendige materialet ikke er lett tilgjengelig, og dels fordi slike unders $\varnothing$ kelser ville vært for omfattende for en masteroppgave.

Etter omfattende søk har jeg funnet 26 høyesterettsavgjørelser hvor tolkningen av et enkeltvedtak har vært et sentralt tema. En av dem er en plenumsdom. Jeg har også med én lagmannsrettsdom og to saker fra Sivilombudsmannen. Ofte handler sakene om at den private part blir sanksjonert eller straffetiltalt for overtredelse av et enkeltvedtak, og deretter bestrider at det foreligger en overtredelse. Tolkningen av enkeltvedtaket er da et sentralt prejudisielt spørsmål i saken. Ti av høyesterettsavgjørelsene er fra perioden 1913-1933, mens resten er fra 1957-2017. De eldste dommene kan ha noe mindre vekt, men de er fortsatt av interesse.

\footnotetext{
${ }^{10}$ Høgberg (2006) s. 84-85.
} 


\section{Tolkningsobjekt}

Enkeltvedtak finner vi på svært mange ulike rettsområder. Vedtakene er ensidig fattet av forvaltningen overfor individualiserte juridiske eller fysiske personer, og de er rettslig bindende. Enkeltvedtak kan være både til gunst og ugunst for den private part. Det kan handle om tillatelser, fritak, forbud og påbud. Enkeltvedtak kan være førsteinstansvedtak, klagevedtak eller omgjøringsvedtak.

Til bruk for oppgaven har jeg hentet inn en del ulike enkeltvedtak, uten at jeg har pretensjoner om en systematisk innsamling. Meningen med innhentingen har vært å skaffe meg en oversikt over hvordan enkeltvedtak er utformet og skape nærhet til det jeg skal analysere. Noen av vedtakene er brukt som eksempler i oppgaven. For det første har jeg mottatt anonymiserte enkeltvedtak fra Kommuneadvokaten i Oslo. ${ }^{11}$ Videre har jeg på skatteetatens hjemmesider funnet skattevedtak i klagesaker, ${ }^{12}$ på Olje- og energidepartementets hjemmesider funnet standardtillatelser, ${ }^{13}$ på Oslo kommunes hjemmesider funnet diverse vedtak ${ }^{14}$ og på Regjeringens hjemmesider funnet konsesjoner innenfor ulike rettsområder ${ }^{15}$. I tillegg siterer ofte domstolene deler av de enkeltvedtakene de tolker.

Utformingen av enkeltvedtak varierer, men parten vil normalt motta et dokument som består av flere deler. Dokumentet inneholder typisk en redegjørelse for sakens tema, bakgrunnsopplysninger, lovhjemmelen/rettsgrunnlaget, begrunnelse og selve vedtaksslutningen (konklusjonen).

Det er vedtaksslutningen som er objektet for tolkningen. Begrunnelsen er så nært knyttet til vedtaksslutningen at det er lett å tenke at den er en del av vedtaket, men det er den ikke. Dette følger av forvaltningsloven, som i §§ 23-25 skiller klart mellom selve vedtaket (slutningen) og begrunnelsen. Begrunnelsen er derimot et sentralt tolkningsmoment. Dette betyr ikke at vedtaksslutningen alltid bare er en eller flere korte setninger. Av og til kan slutningen utgjøre et større dokument som inneholder vilkår, forbehold og så videre. Dersom for eksempel vedtaksslutningen uttrykker at «tillatelsen gis på følgende vilkår», vil de følgende vilkårene være en del av vedtaket.

\footnotetext{
${ }^{11}$ Oslo kommune. Ulike anonymiserte vedtak. Ikke tilgjengelig online. Diverse årstall.

12 Skatteetaten. «Skatteklagenemnda». 2018.

${ }^{13}$ Olje- og energidepartementet. «Petroleumsloven og konsesjonssystemet». 2018.

${ }^{14}$ Reguleringsplaner: Oslo kommune. «Planinnsyn». 2018. Diverse andre vedtak: Oslo kommune. «DocuLive» 2018.

${ }^{15}$ Regjeringen. «Anbud, konsesjoner og brev». 2018.
} 
Tolkning av enkeltvedtak ligner derfor på tolkning av dommer, ${ }^{16}$ hvor tolkningsobjektet er domsslutningen, men hvor domspremissene, påstandene og annen bakgrunn er sentrale tolkningsmomenter, jfr. Rt-1996-1480 (Reksten II) og juridisk teori. ${ }^{17}$

Noen vedtak vil være truffet etter forutgående forhandlinger. Dette er typisk i petroleumssektoren, hvor avtaler og enkeltvedtak vil gå om hverandre. Selv om en tillatelse er basert på forhandlinger, ligger det rettslig sett fortsatt et enkeltvedtak til grunn. Forhandlingene kan likevel få betydning for tolkningen, som i slike tilfeller kan minne om avtaletolkning.

For å gi noen konkrete eksempler på hvordan tolkningsproblemer i enkeltvedtak kan oppstå, har jeg valgt ut tre vedtak fra vidt forskjellige områder.

I et barnevernsvedtak i Oslo kommune er følgende vedtak fattet: «Grorud barneverntjeneste iverksetter råd og veiledning til gutt født xy.xy.xxyy». ${ }^{18}$ Selve vedtaksslutningen sier bare at det iverksettes «råd og veiledning» - to vage ord som ikke gir noen presis angivelse av innholdet. Ut fra denne vedtaksslutningen isolert sett kan foreldrene vanskelig vite hvor ofte de må møte barnevernet og hvilket innhold bistanden får. Som jeg kommer til i punkt 5 , må flere tolkningsmomenter enn bare vedtakets ordlyd få betydning. I dette vedtaket gir begrunnelsen nærmere holdepunkter for hva barneverntjenesten har tenkt å gjennomføre, for der står det at barneverntjenesten skal ta urinprøver av moren som ruser seg og ha jevnlige samtaler med gutten. Urinprøver kan imidlertid synes å ligge så langt unna vedtakets ordlyd at det kan stilles spørsmål ved om det er vedtatt, selv om begrunnelsen gir uttrykk for det.

I et klagevedtak fra Skatteklagenemnda er følgende vedtatt: «Klagen tas til følge». ${ }^{19}$ Hva er det som nå er vedtatt? Dette må i hvert fall tolkes i lys av klagen, som vedtaket uttrykkelig viser til. Her vil det stå hva skattyter mener bør være vedtakets innhold, og det er nå tatt til følge. Vedtaket må også leses i lys av førsteinstansvedtaket. Videre vil Skatteklagenemndas begrunnelse kunne gi opplysninger om hva som er tatt til følge. Det er ikke sikkert at alle punkter i klagen er fulgt, for det kan være både prinsipale og subsidiære påstander.

Det tredje eksempelet er utvinningstillatelser for selskaper som skal gjennomføre oljeboring. Olje- og energidepartementet opererer med standardtillatelser som utfylles konkret overfor de

\footnotetext{
${ }^{16}$ Jeg sikter da til tolkning av dommer med tanke på avgjørelsen mellom partene, og ikke tolkning av dommer som prejudikater.

${ }^{17}$ Fleischer (1981) s. 29-30, Schei mfl. (2013) s. 673, Backer (2015) s. 340 og Skoghøy (2017) s. 1075-1076.

${ }^{18}$ Grorud barneverntjeneste (2012).

${ }^{19}$ Skatteklagenemnda (2018).
} 
oljeselskaper som gis tillatelse. ${ }^{20}$ Vedtakene er lange og inneholder en rekke betingelser, herunder at selskapet binder seg til en 65 -siders standardavtale for petroleumsvirksomhet. ${ }^{21}$ Vedtakene kan reise mange tolkningsproblemer. Hva ligger det for eksempel i at oljeselskapene skal ta «særlig hensyn til fiskeriaktivitetene og til forekomst av kritiske stadier av marine organismer» når programmene for seismiske aktiviteter utformes? ${ }^{22}$ Når er det tatt for lite hensyn, slik at et vilkår i tillatelsen er brutt? Her kan for eksempel forutgående forarbeider til og forhandlinger om vedtaket bli relevante tolkningsmomenter.

Disse enkle eksemplene viser at selve enkeltvedtaket ikke alltid gir klart uttrykk for hvilke rettigheter og plikter som følger av det. Vedtaket må leses i lys av andre tolkningsmomenter. De språklige årsaker til tolkningsproblemene kan være mange, men jeg går ikke nærmere inn på disse. $^{23}$

\footnotetext{
${ }^{20}$ Olje- og energidepartementet. «Petroleumsloven og konsesjonssystemet». 2018.

${ }^{21}$ Olje- og energidepartementet. «Petroleumsloven og konsesjonssystemet». 2018.

${ }^{22}$ Olje- og energidepartementet. «Petroleumsloven og konsesjonssystemet», se «Standardutvinningstillatelse for nummererte runder» punkt 5. 2018.

${ }^{23}$ Se Høgberg (2012) s. 38 flg.
} 


\section{Domstolenes kompetanse og sakstyper}

\subsection{Domstolenes kompetanse til å tolke enkeltvedtak}

Rettspraksis en viktig kilde til tolkningsnormer. Derfor vil jeg, som forklart i punkt 1.2, gå noe inn på domstolenes kompetanse til å tolke enkeltvedtak. Deretter vil jeg i punkt 3.2 gi en oversikt over hvilke sakstyper hvor tolkning av enkeltvedtak kommer opp for domstolene.

Det er klart at domstolene har kompetanse til å tolke enkeltvedtak som en del av tvisteløsningen mellom to parter. ${ }^{24} \mathrm{På} \mathrm{samme} \mathrm{måte} \mathrm{som} \mathrm{det} \mathrm{er} \mathrm{nødvendig} \mathrm{å} \mathrm{tolke} \mathrm{lover} \mathrm{eller} \mathrm{avtaler} \mathrm{for} \mathrm{å} \mathrm{avgjøre}$ tvister, kan det være nødvendig å tolke enkeltvedtak. Det er en lang rekke eksempler på at domstolene har ansett seg kompetente til dette. Fra ulike tidsepoker kan det for eksempel vises til Rt-1931-1138 (Vinmonopolet) (plenumsdom), Rt-1972-32 (Ekspropriasjonstillatelse I) og HR-2017-821-A (Marine Harvest). I sistnevnte dom uttalte Høyesterett:

«Ettersom det har vært et tema under ankeforhandlingene i Høyesterett, nevner jeg at tolkningen av tillatelsene, herunder å fastlegge hvilket utslipp de tillater, er et rettsspørsmål.» (Avsnitt 27.)

Videre uttalte Høyesterett at «[t]olkningen av tillatelsene er en del av fastleggelsen av rettsregelens innhold - ikke en del av bevisvurderingen». (Avsnitt 51.) Det siste innebærer at Høyesterett også i straffesaker kan prøve tolkningen av enkeltvedtak. jfr. straffeprosessloven $§ 306$ annet ledd. Flere av høyesterettsdommene om tolkning av enkeltvedtak er straffedommer.

I Rt-2003-1518 (Soma) skapte imidlertid Høyesteretts ankeutvalg noe uklarhet om domstolenes kompetanse. Spørsmålet i saken var om tolkningen av et enkeltvedtak fra Bergen kommune kunne bringes inn for domstolene ved å anlegge søksmål mot kommunen. Vedtaket gjaldt et pålegg om å flytte en mur hos saksøkerens nabo. Ankeutvalget avviste søksmålet mot kommunen. Ankeutvalget uttalte at kommunen i ettertid hadde presisert sin tolkning av vedtaket og at det nå forelå en «autoritativ fortolkning av vedtaket, som isolert sett ikke kan bringes inn for domstolene» (avsnitt 14) (min kursivering).

Det er her viktig å påpeke at kjennelsen bare gjaldt om saksøkeren hadde rettslig interesse i å reise fastsettelsess $\phi$ ksmål om tolkningen av enkeltvedtaket. Kjennelsen kan ikke ha betydning for om domstolene kan tolke enkeltvedtak prejudisielt, for eksempel for å avgjøre rettmessig-

\footnotetext{
${ }^{24}$ Castberg (1955) s. 133 hevder dette «ikke [er] tvilsomt».
} 
heten av en pålagt sanksjon som følge av overtredelse av et vedtak. Prejudisielt tolker domstolene enkeltvedtak stadig vekk, og det er det uttrykkelig fastslått at domstolene har kompetanse til i HR-2017-821-A (Marine Harvest) - som kom etter Rt-2003-1518 (Soma).

Selv om Rt-2003-1518 (Soma) bare gjaldt fastsettelsess $\phi$ ksmål, kan den etter mitt syn heller ikke være riktig for slike saker. Adgangen til å reise søksmål for domstolene beror på om vilkårene i tvisteloven $\S 1-3$ er oppfylt. Det ligger utenfor min oppgave å gå inn på en nærmere drøftelse av disse vilkårene. Jeg nøyer meg med å påpeke at Høyesterett har behandlet andre fastsettelsessøksmål som beror på tolkningen av enkeltvedtak, for eksempel i Rt-1957-375 (Konsesjonsvilkår) og Rt-1972-1050 (Ekspropriasjonstillatelse II). I juridisk teori hevder Backer at Rt-2003-1518 (Soma) er en «misforståelse». ${ }^{25}$ Backer fremholder at «[h]vis sфksmålet gjelder innholdet av et enkeltvedtak - dvs. hvordan enkeltvedtaket skal forstås, er s $\phi$ ksmålsgjenstanden konkret og ikke uttrykk for noen generell rettssetning. Et slikt sфksmål oppfyller kravet til sфksmålsgjenstand.» ${ }^{26}$ (Min kursivering.) Backer støttes av Hopsnes, som også mener det bør sees bort fra kjennelsen på grunn av all annen rettspraksis som peker i motsatt retning. ${ }^{27}$

\subsection{Sakstyper om tolkning av enkeltvedtak}

De sakene som kommer opp for domstolene om tolkning av enkeltvedtak kan sorteres i fem hovedgrupper, hvorav de to første gruppene er mest sentrale.

Den første gruppen er fastsettelsess $\varnothing$ ksmål hvor det kreves dom for et rettighets- eller pliktforhold som beror på hvordan et enkeltvedtak skal tolkes. For eksempel kan en som har fått byggetillatelse være uenig med kommunen om hvor stort bygget kan være. Før byggestart reiser derfor utbyggeren fastsettelsessøksmål og krever dom på hvor stort bygget kan være. Domstolens tolkning i slike saker vil bindende avgjøre mellom partene hva som følger av vedtaket. Dommen i Rt-1972-1050 (Ekspropriasjonstillatelse II) illustrerer godt slike fastsettelsessøksmål. Saken gjaldt spørsmålet om en ekspropriasjonstillatelse omfattet sjøgrunnen tilstøtende et landområde, og dermed hvem som nå eide sjøgrunnen. Den private part krevde dom for at hun var eier og staten krevde $\mathrm{i}$ et motsøksmål dom for at den var eier (se nærmere om dommen i punkt 5.3). Det er ikke mange fastsettelsessøksmål blant de dommer jeg har funnet om tolkning av enkeltvedtak, men de som foreligger er likevel interessante i det domsmaterialet jeg bygger på. I disse dommene er tolkningen av enkeltvedtaket det sentrale tvistetemaet og tolkningen er derfor ofte grundig behandlet.

\footnotetext{
25 Backer (2015) s. 215.

${ }^{26}$ Backer (2015) s. 215.

${ }^{27}$ Hopsnes (2017) s. 274.
} 
Den andre gruppen er hvor tolkningen av enkeltvedtak kommer opp prejudisielt i saker om påstått overtredelse av bestemmelser i et enkeltvedtak. Det kan være saker om gyldigheten av ilagte sanksjoner eller spørsmål om straff for overtredelse av vedtaket. Tolkningen blir ikke da bindende avgjort, men den er et nødvendig ledd i å avgjøre sakens utfall. Et eksempel kan være et selskap som slipper ut mer forurensning enn det myndighetene mener selskapets utslippstillatelse gir adgang til. Selskapet kan bli pålagt å rette opp forholdet og ilagt sanksjoner i form av gebyr. Dersom selskapet er uenig i myndighetens tolkning av tillatelsen kan det bringe gyldigheten av pålegget eller sanksjonene inn for domstolene. Domstolene må da tolke tillatelsen for å vurdere om pålegget eller sanksjonene er rettmessig(e). Ved alvorlige overtredelser kan det bli reist tiltale for overtredelse, og da kommer tolkningen av enkeltvedtak opp i straffesaken. Et av mange eksempler på slike saker er HR-2017-821-A (Marine Harvest), som gjaldt tiltale for overtredelse av en forurensningstillatelse. Tolkning av tillatelsen ble da et sentralt spørsmål i straffesaken (se nærmere om dommen i punkt 5.11). De fleste dommer jeg har funnet om tolkning av enkeltvedtak er i denne gruppen, og disse sakene er derfor de viktigste i det domsmaterialet jeg bygger på.

Tredje gruppe er søksmål om gyldigheten av enkeltvedtak. I slike saker må også vedtaket tolkes for å fastslå innholdet. Vanligvis vil det her være enighet om tolkningen, men ved uenighet må domstolene ta prejudisielt stilling til tolkningen av vedtaket. Selv om søksmål om gyldigheten av et vedtak er det vanligste i forvaltningsretten, er det imidlertid sjeldent samtidig uenighet om tolkningen av vedtaket. I domsmaterialet mitt er det ingen slike saker.

Fjerde gruppe er søksmål fra tredjemenn. Adgangen til å reise søksmål etter tvl. §§ 1-3 og 1-4 er ikke strengt begrenset til egne rettigheter og plikter, jfr. forarbeidene. ${ }^{28}$ Dette betyr at det kan være aktuelt med søksmål fra tredjemenn om alle de tre typene søksmål som er nevnt ovenfor, noe Rt-2003-1518 (Soma) er et eksempel på. Søksmål fra tredjemenn er likevel ikke sentralt for oppgaven, ettersom disse som regel handler om gyldigheten av vedtaket.

Femte gruppe er saker om lovtolkning hvor den ene parten påberoper seg forvaltningspraksis som rettskilde for et bestemt tolkningsresultat. En asylsøker hevder for eksempel at forvaltningspraksis i asylsaker tilsier at en bestemmelse i utlendingsloven skal forstås i tråd med hans syn. Når domstolene da skal vurdere den fremlagte forvaltningspraksis, blir domstolene nødt til å tolke vedtakene i den påberopte praksis. Heller ikke denne gruppen er viktig for oppgaven, fordi det er sjeldent domstolene i denne sammenheng uttaler mye om tolkningen av vedtakene. I domsmaterialet mitt er det ingen slike saker.

\footnotetext{
${ }^{28}$ Ot.prp. nr. $51(2004-2005)$ s. 364.
} 


\section{$4 \quad$ Tolkningsformål}

\subsection{Innledning}

Ved fastleggelsen av hvilke rettigheter og plikter som følger av et enkeltvedtak, kan det stilles spørsmål ved hvilket formål fastleggelsen har. Er formålet å finne frem til hva forvaltningen mente å gi uttrykk for i vedtaket (subjektivt)? Eller er formålet å finne frem til en alminnelig forståelse av vedtakets ordlyd (objektivt)? Eller er det ingen klare formål som styrer tolkningen?

I fremstillinger om tolkning av andre rettslig bindende tekster, drøftes det som regel om det gjelder et objektivt eller et subjektivt tolkningsformål. Ved tolkning av lover starter man med en alminnelig forståelse av ordlyden (objektivt), men søker deretter til kilder som kan si noe om hva lovgiver har ment (subjektivt), og så går man videre til andre kilder, uten at det synes å være ett bestemt formål med tolkningen. ${ }^{29}$ For avtaler er det et objektivt tolkningsformål, med mindre en felles partsoppfatning kan bevises (subjektivt). ${ }^{30}$ For traktater gjelder det et lignende utgangspunkt i et objektivt formål, men også kilder av mer subjektiv karakter er relevant. ${ }^{31}$ For testamenter gjelder et tydeligere subjektivt formål. ${ }^{32}$ For dommer gjelder et objektivt formål. ${ }^{33}$

Ved tolkning av enkeltvedtak vil et objektivt tolkningsformål ivareta de forventninger den private part får ved å lese vedtaket. Det er fortsatt forvaltningen som bestemmer vedtakets ordlyd, men forvaltningen må uttrykke seg tilstrekkelig klart. Når vedtaket først er fattet, vil man med et slikt formål måtte holde seg til ordlyden og andre momenter som kan si noe om en objektiv forståelse av ordene, slik som for eksempel ordenes betydning i hjemmelsloven og annen rett. Et slikt formål vil best samsvare med at forvaltningen er bundet av sine vedtak (utenom omgjøringsmulighetene).

Et subjektivt tolkningsformål vil i større grad ivareta forvaltningens mening med vedtaket. Dette vil kunne fremme forvaltningens målsetninger og verdier. Tolkning i tråd med forvaltningens målsetninger vil også vise lojalitet til forvaltningen. Ved et slikt formål vil man særlig vektlegge momenter som kan kaste lys over hva forvaltningen har ment med vedtaket, som for eksempel begrunnelsen og vedtakets forarbeider.

\footnotetext{
${ }^{29}$ Eckhoff (2001) s. 152.

${ }^{30}$ Woxholth (2017) s. 406.

${ }^{31}$ Ruud og Ulfstein (2018) s. 93-101.

${ }^{32}$ Lødrup og Asland (2018) s. 174.

${ }^{33}$ Schei mfl. (2013) s. 673.
} 
I punkt 4.2 vil jeg gjennomgå hvilke tolkningsformål som er hevdet i juridisk teori om tolkning av enkeltvedtak. Deretter vil jeg i punkt 4.3 vise at det etter høyesterettspraksis ikke er ett enkelt tolkningsformål som gjelder. Høyesterett er mer opptatt av konkrete tolkningsmomenter enn hva som er tolkningsformålet. Konklusjonen på problemstillingen om tolkningsformål kommer i punkt 4.4.

\subsection{Teorier i litteraturen}

Mye av det som i juridisk litteratur er skrevet om tolkning av enkeltvedtak har handlet om tolkningsformål. Denne litteraturen kan grovt deles i tre grupper.

På den ene siden har vi de som har tatt til orde for et subjektivt tolkningsformål. Boe skriver at det «tross alt er forvaltningens mening som i utgangspunktet må bety mest for å få kartlagt hva vedtaket går ut på» (min kursivering). ${ }^{34}$ Samtidig hevder Boe at forarbeidene til vedtaket må spille en mindre rolle som tolkningsmoment, delvis på grunn av manglende tilgjengelighet for den private part. ${ }^{35}$ Det siste er ikke så logisk dersom man skal søke hva forvaltningen mente, og det tyder på at Boe ikke hevder et strengt subjektivt tolkningsformål. I Boe og Woxholth begrunnes en subjektiv tolkning med at vedtakene er «fattet på grunnlag av det offentliges «høyhetsrett», som til syvende og sist er hjemlet i konstitusjonen». ${ }^{36}$ Hvorfor dette skulle tilsi et subjektivt tolkningsformål forklares ikke, og det er ikke alle typer enkeltvedtak som er fattet på grunnlag av det offentliges «høyhetsrett».

På den andre siden finner vi forfattere som hevder at det gjelder et objektivt tolkningsformål. Knoph tar til orde for dette, og mener at ikke engang en felles tekstforståelse (se punkt 5.3) mellom staten og den private part kan gå foran ordlyden, ettersom andre også kan berøres av vedtaket. ${ }^{37}$ Castberg hevder at det ikke kan være formålet å finne hva forvaltningsorganet har ment, men at forvaltningens synbare forutsetninger likevel kan få betydning. ${ }^{38}$ Bernt og Rasmussen kommer inn på spørsmålet under en drøftelse av adgangen til å rette feil i vedtaket. ${ }^{39}$ De skriver at «den alminnelige regel må være at vedtaket er det som er kommet skriftlig til uttrykk i meddelelsen til parten», som en motsetning til hva «forvaltningsorganet har ment å gjøre». ${ }^{40}$

\footnotetext{
${ }^{34}$ Boe (2010) s. 263.

${ }^{35}$ Boe (2010) s. 263.

${ }^{36}$ Boe og Woxholth (2013) s. 89.

${ }^{37}$ Knoph (1927) s. 18.

${ }^{38}$ Castberg (1955) s. 148-150.

${ }^{39}$ Bernt og Rasmussen (2010) s. 334.

${ }^{40}$ Bernt og Rasmussen (2010) s. 334.
} 
En mellomgruppe er Aanerud og Hopsnes. Aanerud tar til orde for en tolkning av reguleringsplaner, som er en type enkeltvedtak, ${ }^{41}$ etter omtrent de samme prinsipper som lovtolkningen, hvor det altså ikke er ett klart bestemt formål. ${ }^{42}$ Hopsnes tar ikke et klart standpunkt, og konkluderer med at tolkningsformålet for enkeltvedtak ikke er avklart. ${ }^{43}$

Det har også vært skrevet om tolkningen av forhåndstilsagn fra forvaltningen. Forhåndstilsagn blir bindende enten ved avtale eller gjennom enkeltvedtak. ${ }^{44}$ Fordi en del forhåndstilsagn vil treffes gjennom enkeltvedtak, kan teori om tolkning av forhåndstilsagn tenkes å ha betydning. Det som er skrevet om tolkning av forhåndstilsagn gir imidlertid liten hjelp for tolkningen av enkeltvedtak. For det første er det uklart hvordan forhåndstilsagn skal tolkes. ${ }^{45}$ For det andre bærer litteraturen preg av et fokus på forskjellene mellom tolkning av avtaler mellom private og avtaler mellom det offentlige og private, og ikke tolkning av enkeltvedtak.

Juridisk teori gir altså ikke noe entydig svar på problemstillingen. Forfatterne inntar ulike utgangspunkter, men likevel er det kanskje ikke så stor uenighet som det umiddelbart kan fremstå. Alle synes uansett å mene at man starter med ordlyden og deretter supplerer med andre momenter. Avhengig av synet på tolkningsformålet, er det imidlertid noe uenighet om ulike momenters relevans og vekt.

\subsection{Høyesterettspraksis om tolkningsformål}

Høyesterett synes å legge til grunn at utgangspunktet er en objektiv tolkning av vedtakets ordlyd (slutningen), før man deretter ser på andre momenter av både objektiv og subjektiv karakter. Høyesterett synes altså ikke å la seg styre av ett enkelt tolkningsformål, men er mer opptatt av konkrete tolkningsmomenter. De dommene hvor Høyesterett klarest har uttalt noe om formålet med tolkningen er tre dommer fra 1930-tallet.

Rt-1930-1305 (Laererlфnn I) gjaldt tolkningen av en beslutning fra bystyret om lønnsøkning for lærere. Beslutningen må antakelig anses som et enkeltvedtak, fordi beslutningen ga rettigheter

\footnotetext{
${ }^{41}$ Ot.prp. nr. 32 (2007-2008) s. 65.

${ }^{42}$ Aanerud (2017) s. 111-172 punktene 3.2.3-3.2.5.

${ }^{43}$ Hopsnes (2017) s. 275.

${ }^{44}$ Eckhoff og Smith (2018) s. 424-425.

${ }^{45}$ Bernt (1981) s. 111-112, Hopsnes (2017) s. 306 og Eckhoff og Smith (2018) s. 428.
} 
til bestemte personer (lærerne i kommunen) og Høyesterett drøftet tolkningen av «forvaltningsakter». ${ }^{46}$ En lærer mente at han som følge av vedtaket hadde krav på høyere lønn enn kommunen ville gi han. Kommunen hevdet derimot at lærerne måtte bevise at bystyret hadde ment å binde seg til høyere lønn for lærerne. Høyesterett var uenig med kommunen og uttalte at:

«... [det] er uten betydning hvad bystyrets medlemmer maatte ha ment med beslutningen. Denne maa - som forvaltningsakter i almindelighet - fortolkes efter sitt eget innhold og paa bakgrunn av de forhold, som har foranlediget den, uten at det kan komme i betraktning hvad de enkelte personer, som har deltatt i beslutningen, har ment om dens rekkevidde.» (Side 1307.)

Høyesterett ville altså ikke legge vekt på hva bystyret hadde ment, men la derimot avgjørende vekt på hvordan vedtaket fremstod. Dette indikerer en objektiv tolkning. Likevel var også de forhold som «foranlediget» vedtaket relevant, noe som indikerer at også mer subjektive forhold kunne få betydning.

Den andre dommen er Rt-1931-582 (Tyldal). Sognestyret i Tyldal, som var en underkommunal enhet i kommunen, hadde ervervet en skogeiendom som de senere pantsatte til en bank. Gårdbrukerne i sognet mente at pantsettelsen ikke var gyldig og begrunnet det med en påstand om at de vedtekter sognestyret hadde fastsatt for skogeiendommen la eiendomsretten til dem. Høyesterett kom etter en konkret tolkning av vedtektene til at det ikke var grunnlag for gårdbrukernes påstand, og at pantsettelsen derfor var gyldig. Sognestyrets fastsatte vedtekter må antakelig anses som enkeltvedtak, fordi de kun gjaldt sognets gårdbrukeres rettigheter og plikter til skogområdet og Høyesterett omtalte vedtektene som «forvaltningsakt». ${ }^{47} \mathrm{Om}$ tolkningen uttalte Høyesterett:

«Og endelig maa man ogsaa huske paa at det her gjelder en forvaltningsakt, og at en saadan i særlig grad maa fortolkes objektivt.» (Side 587) (min kursivering).

Høyesterett uttalte altså at en «forvaltningsakt» skal tolkes objektivt. Deretter vektla Høyesterett imidlertid også vitneforklaringer om hva et av medlemmene i sognestyret hadde ment med utferdigelsen (side 587). Dette subjektive momentet tilsier at det i hvert fall ikke var en ren objektiv tolkning.

\footnotetext{
${ }^{46}$ Se Castberg (1955) s. 138 sin definisjon av «forvaltningsakt». Hopsnes (2017) s. 273-274 drøfter også dommen under denne synsvinkelen.

${ }^{47}$ Se Castberg (1955) s. 138 sin definisjon av «forvaltningsakt». Hopsnes (2017) s. 274 nevner også denne dommen som et eksempel på tolkning av enkeltvedtak.
} 
Den tredje dommen er plenumsdommen Rt-1931-1138 (Vinmonopolet). ${ }^{48}$ Staten hadde gitt Vinmonopolet konsesjon til import og omsetning av brennevin på nærmere fastsatte vilkår i konsesjonen. Senere påla Stortinget kommuneskatt etter byskatteloven på aksjonærenes inntekter fra Vinmonopolet. Tvisten gjaldt om konsesjonen innskrenket Stortingets mulighet til å pålegge Vinmonopolets aksjonærer kommuneskatt for inntektene fra import og omsetning, ettersom konsesjonen ikke inneholdt noen bestemmelse om skattlegging. Vinmonopolets aksjonærer hevdet det var en forutsetning at det ikke skulle pålegges. Høyesteretts flertall (11 mot 10) kom til at Stortingets mulighet til å skattlegge Vinmonopolets aksjonærer ikke var innskrenket, men det interessante i vår sammenheng er at Høyesterett uttalte at «[d]ette spørsmaal maa avgjøres efter en objektiv fortolkning av koncessionen under hensyntagen til den Stortings-beslutning og de forhandlinger som ligger til grunn for den.» (Side 1139) (min kursivering). Høyesterett skriver altså uttrykkelig at konsesjonen skal tolkes objektivt, men deretter påpeker Høyesterett at andre faktorer, som de forutgående forhandlinger, skal tas i betraktning. Meningen med å vurdere de forutgående forhandlinger må være å kaste lys over hva meningen med vedtaket er, noe som indikerer et mer subjektivt formål.

Blant mindretallet var det ingen klare uttalelser om tolkningsformålet, men dommer Lie (med tilslutning av flere) berørte så vidt spørsmålet. Han uttalte at fordi forholdet bar preg av å være en avtale, så han ikke grunn til å «anlegge en prinsipielt annen fortolkning paa koncessionen, saaledes som den fremtreder i sitt eget innhold, enn paa privatrettslige rettshandler» (side 1147). Dette kan tilsi at uten preget av avtaleforhold ville han sagt seg enig med flertallets uttalelser om en objektiv tolkning.

I alle tre dommene uttalte altså Høyesteretts flertall at det skal foretas en objektiv tolkning. ${ }^{49}$ Dette gir imidlertid ikke grunnlag for å konkludere med at det gjelder ett klart tolkningsformål, fordi Høyesterett i alle tre dommene vurderte både objektive og subjektive momenter ved fastleggelsen av vedtakenes innhold. Høyesterett fulgte altså ikke konsekvent sine uttalelser om en objektiv tolkning. Etter min mening er det derfor mer nærliggende å forstå Høyesterett slik at det skal tas utgangspunkt i en objektiv tolkning av ordlyden, men deretter er både objektive og subjektive momenter relevante i tolkningen.

Heller ikke høyesterettspraksis etter 1930-tallet gir grunnlag for å slutte at det gjelder ett bestemt tolkningsformål. Etter 1930-tallet har jeg ikke funnet at Høyesterett uttaler seg direkte

\footnotetext{
${ }^{48}$ En tilsvarende sak, Rt-1931-1158, ble avgjort dagen etter under henvisning til begrunnelsen i plenumsdommen. Til sakskomplekset hører også Rt-1929-529, men den samme konsesjonen ble drøftet mer inngående i plenumsdommen.

${ }^{49}$ Hos Castberg (1955) s. 149 nevnes også Rt-1929-771 (Oljepris) som et eksempel på at Høyesterett uttaler seg om tolkningsformålet ved enkeltvedtak, men etter mitt syn gjelder dommen avtaletolkning, jfr. Huser (1983) s. 403 og Eckhoff og Smith (2018) s. 427. Dommen ville uansett ikke endret konklusjonen.
} 
om formålet med tolkningen. Høyesterett har istedenfor fokusert på å løse sakene gjennom konkrete tolkningsmomenter av både objektiv og subjektiv karakter, jfr. nedenfor i punkt 5 .

\subsection{Oppsummerende bemerkninger}

Tilsvarende de betraktninger Eckhoff og Skoghøy gjør seg om lovtolkning, ${ }^{50}$ virker det altså heller ikke som om tolkningen av enkeltvedtak preges av ett enkelt formål. Domstolenes holdning bærer mer preg av å veie ulike hensyn og dermed kombinere formålene. Domstolene vil skape forutberegnelighet ved å ta utgangspunkt i ordlyden og andre objektive momenter. Videre vil de ved å trekke inn subjektive momenter også vise lojalitet overfor forvaltningens forutsetninger, selv om formålet ikke primært er å finne hva forvaltningen har ment. Forvaltningens oppgave i denne sammenheng er å gjennomføre Stortingets lover. Dette tilsier en viss lojalitet overfor forvaltningen, men ikke nødvendigvis i samme grad som overfor lovgiver. Endelig er nok domstolene gjennomgående opptatt av at resultatet skal fremstå som rimelig eller godt, slik Eckhoff påpeker om lovtolkning..$^{51}$

På denne bakgrunn mener jeg det er mer interessant å analysere hvilke momenter domstolene vil vektlegge og hvilken vekt disse har, enn å drøfte om tolkningsformålet er subjektivt eller objektivt. En analyse av slike momenter er mer praktisk for den som skal tolke et enkeltvedtak, fordi det gir en tydeligere fremgangsmåte for hvordan man fastlegger hvilke rettigheter og plikter som følger av vedtakene. Dette analyseres i neste punkt, som er oppgavens største del. Denne tilnærmingen er også blitt vanlig i litteratur om tolkning av andre rettslig bindende tekster som for eksempel lover, avtaler, traktater, testamenter og dommer - hvor fremstillingene i nyere tid vier mer plass til konkrete tolkningsmomenter enn tolkningsformålet. ${ }^{52}$

\footnotetext{
${ }^{50}$ Eckhoff (2001) s. 152-154 og Skoghøy (2018) s. 24.

${ }^{51}$ Eckhoff (2001) s. 152-154.

${ }^{52}$ Eckhoff (2001) fremstillingen i sin helhet, Woxholth (2017) s. 405-439, Ruud og Ulfstein (2018) s. 93-101, Lødrup og Asland (2018) s. 173-193, Schei mfl. (2013) s. 673-674 og Skoghøy (2017) s. 1075-1076.
} 


\section{$5 \quad$ Tolkningsmomenter}

\subsection{Tolkningsprosessen - en avveining av tolkningsmomenter}

Rettspraksis og andre rettskilder jeg skal gjennomgå her i punkt 5 viser at en rekke momenter er relevante ved tolkning av enkeltvedtak. Utgangspunktet er utvilsomt vedtakets ordlyd, men også andre tolkningsmomenter av både objektiv og subjektiv karakter er relevante og viktige.

Ved tolkning av enkeltvedtak må det derfor foretas en avveining av relevante tolkningsmomenter. Slike avveininger foretas også ved tolkning av andre rettslige tekster, ${ }^{53}$ og kalles ved lovtolkning ofte for «Eckhoffs avveiningsmodell». ${ }^{54}$

I punktene 5.2-5.13 vil jeg analysere hvilke momenter som er relevante i denne avveiningen ved tolkningen av enkeltvedtak og hvilken vekt disse momentene har i avveiningen. Listen over tolkningsmomenter er ikke nødvendigvis uttømmende. Det kan nok tenkes flere momenter som kan ha betydning for tolkningen av ulike vedtak. Listen fors $\varnothing$ ker likevel å gi en oversikt over de mest sentrale momenter. I tillegg har jeg lagt inn et moment som har blitt anført som vektig, uten at jeg er enig i det.

Relevans- og vektspørsmål og avveiningen av tolkningsmomentene mot hverandre vil bli drøftet fortløpende under de ulike tolkningsmomentene. Det er ofte de samme argumentene som styrer relevansen og vekten, slik at jo sterkere grunner det er for å ta i betraktning et moment, jo vektigere vil det også være i avveiningen mot andre tolkningsmomenter.

Slutningsspørsmål omtales i varierende grad. Ordlydsslutninger får et eget underpunkt, fordi ordlyden er utgangspunktet for tolkningen. Omtalen blir derimot mer kortfattet for andre momenter, selv om det også her må foretas slutninger.

Hvilke tolkningsmomenter som i de konkrete tilfeller tillegges størst vekt, vil bero på hva som foreligger av tolkningsmomenter i saken. Videre vil det bero på hvilke slutninger som kan trekkes fra momentene, for eksempel vil en klar ordlyd ha større vekt enn en uklar ordlyd. Det er likevel klart at noen momenter generelt har større vekt enn andre, noe rekkefølgen på underpunktene til en viss grad reflekterer. Denne rekkefølgen gjelder imidlertid ikke unntaksfritt. For det første vil den mulige betydningen av om vedtaket er til gunst eller ugunst bli drøftet tidlig, fordi det er blitt anført å ha stor betydning - og dersom det hadde vært tilfellet, ville det ha påvirket vekten av de øvrige tolkningsmomentene. Som det fremgår av drøftelsen nedenfor har

\footnotetext{
${ }^{53}$ Eng (2007) s. 164-165 og 169-170.

${ }^{54}$ Se for eksempel Boe (2012) s. 174.
} 
det imidlertid etter mitt syn liten eller ingen selvstendig betydning om vedtaket er til gunst eller ugunst. For det andre har de særskilte tolkningsmomentene for klagevedtak og omgjøringsvedtak ofte stor vekt når de først er aktuelle, men det er praktisk å omtale de til slutt.

Rettspraksis og juridisk teori har, som i avtaleretten, først og fremst betydning som kilde til hvilke tolkningsnormer som gjelder. Det er derimot lite aktuelt at det for et konkret enkeltvedtak foreligger en dom med prejudikatsverdi eller en omtale i juridisk teori, og derfor vil ikke rettspraksis og juridisk teori tas opp som mulige tolkningsmomenter.

Jeg starter med ordlyden (punkt 5.2), som er det mest sentrale momentet. Neste punkt er om en felles tekstforståelse kan gå foran den alminnelige forståelsen av ordlyden (punkt 5.3). Deretter drøfter jeg om det har betydning om et vedtak er til gunst eller ugunst (punkt 5.4). Etter dette drøfter jeg en rekke momenter som ofte har stor vekt (punktene 5.5-5.8), som vedtakets begrunnelse, en eventuell søknad, hjemmelen for vedtaket og annen rett. Når det er gjort, går jeg over til noe mindre vektige momenter (punktene 5.9-5.12), som vedtakets forarbeider, forhandlinger og annen forhistorie, forvaltningspraksis, etterfølgende omstendigheter og reelle hensyn. Til slutt kommer særskilte momenter for klagevedtak og omgjøringsvedtak (punkt 5.13).

\section{$5.2 \quad$ Ordlyden}

\subsubsection{Utgangspunktet for tolkningen}

Etter fvl. $§ 23$ skal enkeltvedtak i all hovedsak være skriftlige og vedtakets ordlyd er derfor utgangspunktet for tolkningen. Det er forvaltningen som har kompetansen til å fatte vedtak, og rettsanvendere må derfor vise lojalitet til den ordlyden forvaltningen har valgt.

Med vedtakets ordlyd sikter jeg til ordlyden i vedtaksslutningen, som forklart i punkt 2. Dette inkluderer eventuelle vilkår, forbehold og andre bestemmelser i slutningen. Forvaltningens begrunnelse for vedtaket er ikke en del av dette, men er et sentralt tolkningsmoment (se punkt $5.5)$.

De aller fleste enkeltvedtak oppstår det aldri tvist om, fordi vedtakene ofte er klare og tydelige. De saker som havner i domstolene, og særlig de som havner i Høyesterett, er unntakene som har bydd på tolkningstvil. Det er derfor viktig å huske på at når domstolene ser til andre momenter utenfor ordlyden, så er det fordi ordlyden er så uklar at det foreligger et behov for å vurdere momenter som kan klargjøre ordlydens betydning.

Selv om høyesterettssakene ofte byr på tvilsomme tolkningsspørsmål, vil likevel Høyesterett ofte starte og slutte med en ordlydstolkning i snever forstand, uten at andre momenter får særlig 
betydning. Dette er nettopp fordi det er ordlyden forvaltningen har skrevet, og den gir berettigede forventninger hos den private part. Jeg skal gi noen eksempler som viser dette.

Det første eksempelet er HR-2011-1652-U (Statoil). I en sak om foretaksstraff for forurensning anførte Statoil at lagmannsrettens tolkning av forurensningstillatelsen deres var feil. I søknaden forut for tillatelsen hadde selskapet søkt om rett til mottaksanlegg for oljeholdig spylevann og sludgevann fra skip. I tillatelsen fikk Statoil også rett til det samme fra oljeplattformer. Dette mente Statoil ga grunn til å tro at tillatelsen generelt skulle tolkes utvidende, slik at også en type avfall som verken var oljeholdig spylevann eller sludgevann var tillatt. Høyesteretts ankeutvalg holdt seg kun til ordlyden og sa at dette var utenfor tillatelsen.

Et annet eksempel er Rt-1971-401 (Avkjфringstillatelse). I en tillatelse gitt til et selskap sto det at det gis «tillatelse til å legge avkjørsel til bensinservicestasjon fra fylkesveg nr. 334 ved Pors stadion» (side 405). Som følge av kommunikasjonen forut for tillatelsen mente selskapet at avkjørselstillatelsen både gjaldt til bensinstasjon og kjøpesenter. Dette forutsatte selskapet da det senere planla utbygging av et kjøpesenter, og ble overrasket når staten mente noe annet. Selskapet krevde erstatning for forsinkelsen av utbyggingen av kjøpesenteret. Høyesterett holdt seg i all hovedsak til ordlyden og uttalte at $«[\mathrm{~h}]$ vis selskapet ikke oppdaget begrensningen i den tillatelse det mottok, kan det bare bebreide seg selv at det ikke har lest tillatelsen med omhu.» (Side 404.)

Ytterligere eksempler på dette gir Rt-1917-402 (Apotekbevilling) på side 402-403, Rt-1974149 (Kommunal renovasjon) på side 155 og Rt-1983-1067 (Virksomhetstillatelse) på side 1070-1071. Selv om Høyesterett i disse sakene brukte plass på andre rettsspørsmål av betydning for partene, var selve tolkningen av enkeltvedtakene basert på en ren ordlydstolkning. Det klare utgangspunktet er altså vedtakets ordlyd.

\subsubsection{Ordlydsslutninger}

Jeg skal her gå nærmere inn på ulike regler for ordlydsslutninger. Flere av disse slutningsreglene kjenner vi fra tolkning av andre rettslige tekster, og mange av de må gjelde også for enkeltvedtak.

Utgangspunktet ved ordlydsslutninger er en alminnelig forståelse av ordlyden. Med «alminnelig forståelse» menes en forståelse basert på hvordan ord og uttrykk i teksten vanligvis forstås. For enkeltvedtak er det nok sjeldent at ordenes alminnelige betydning endrer seg i perioden vedtaket gjelder, men prinsipielt sett må det være riktig å legge til grunn den alminnelige forståelsen av ordene på vedtakstidspunktet. 
Et unntak fra at den alminnelige forståelsen av ordlyden skal legges til grunn, gjelder ord og uttrykk som forvaltningen har definert i vedtaket. Det må da legges til grunn den definerte forståelsen av ordene. For eksempel er det i standardtillatelsen for olje- og gasstillatelser punkt 4 bokstav g en slik definisjon av ordet «undersøkelsesbrønn»:

«en brønn som undersøker en klart definert geologisk enhet (avgrenset etter ett eller flere av følgende kriterier: struktur, litologi, facies eller trykk) og som i den vedtatte boreposisjon gjennomborer alle prospektive intervaller som ligger innenfor arbeidsforpliktelsen som definert ovenfor.» ${ }^{55}$

Dette må innebære at man skal følge denne forståelsen av ordet «undersøkelsesbrønn» i tillatelsen, og ikke en antatt alminnelig forståelse av ordet.

Ord og uttrykk kan også være definert i loven som hjemler vedtaket. Dersom de samme ord eller uttrykk er benyttet i vedtaket er det naturlig å forstå dem i tråd med lovens legaldefinisjon. Hvis en skjenkebevilling hjemlet i alkoholloven bruker uttrykket «alkoholholdig drikk», må dette ha samme innhold som legaldefinisjonen av det tilsvarende uttrykket i alkoholloven $\S 1$ 3 - hvis ikke annet er sagt i vedtaket.

Selv om ikke hjemmelsloven har en legaldefinisjon for relevante ord og uttrykk, vil det fortsatt være naturlig å forstå ordlyden i vedtaket på samme måte som tilsvarende ordlyd i hjemmelsloven. Dette gir Rt-1957-375 (Konsesjonsvilkår) et eksempel på. Saken hadde to hovedspørsmål, hvor det andre spørsmålet er det interessante i denne sammenheng. Fire bedrifter var i konsesjonsvilkår pålagt å skaffe «arbeiderne» den til enhver tid nødvendige legehjelp og holde et nødvendig sykehus. Et av spørsmålene i saken var om ordlyden «arbeiderne» kun omfattet selve arbeiderne eller om det også omfattet arbeidernes familier, funksjonærene og funksjonærenes familier. Høyesteretts flertall (annenvoterende i dette spørsmålet) påpekte at selve hjemmelen for å pålegge vilkår til konsesjonen bare brukte ordet «arbeiderne», mens det i andre bestemmelser i loven var brukt uttrykk som «arbeiderne og funksjonærene» og «arbeiderne og disses familier». Høyesterett mente at «denne språkbruk ikke er tilfeldig» (side 380), og siktet til at «arbeiderne» i hjemmelen bare betydde selve arbeiderne. Fra dette sluttet Høyesterett at «arbeiderne» måtte forstås på samme måte i konsesjonsvilkårene.

Om ikke annet fremgår av sammenhengen, må det også legges til grunn at et ord eller uttrykk har den samme betydning gjennom hele vedtaket. Det gjelder enten man følger en uttrykkelig definert betydning eller den alminnelige betydningen.

\footnotetext{
${ }^{55}$ Olje- og energidepartementet. «Petroleumsloven og konsesjonssystemet», se «Standardutvinningstillatelse for nummererte runder» punkt 4 bokstav g. 2018.
} 
Videre må spesielle reguleringer gå foran generelle (lex specialis). Dette er ofte aktuelt for lengre enkeltvedtak med mange underoverskrifter, noe som også illustrerer hvordan overskrifter og underoverskrifter får betydning for tolkningen (systeminnrettet tolkning). Som et eksempel kan vi se på Posten Norge AS sin konsesjon til å tilby leveringspliktige posttjenester i Norge. Under punkt 2.4 om «Utlevering», skilles det mellom «2.4.1 Utleveringssted» og «2.4.2 Utleveringssted for funksjonshemmede». ${ }^{56}$ Det følger av disse underpunktene andre regler for utlevering av post til funksjonshemmede enn ellers. Her er det utvilsomt slik at man for de funksjonshemmende ikke skal følge de generelle regler om utlevering i punkt 2.4.1, men derimot de spesielle reglene i punkt 2.4.2.

Ved åpenbare feil i teksten, må teksten forstås etter forvaltningens tilsiktede betydning. Med «åpenbart» sikter jeg til feil som forvaltningen, parten og andre berørte opplagt må forstå er feil. For eksempel rene skrivefeil. I slike tilfeller må alle kunne legge det innhold i vedtaket som var ment fra forvaltningens side, selv om det er til skade for den private part. Slike feil hevder Eckhoff og Smith at forvaltningen må kunne rette opp i vedtakets tekst uten å anvende omgjøringsreglene. ${ }^{57}$ Bernt og Rasmussen mener derimot at åpenbare feil må rettes opp i medhold av omgjøringsregelen i fvl. $\S 35$ femte ledd etter «alminnelige forvaltningsrettslige regler». ${ }^{58}$ Det innebærer at omgjøringsreglene anvendes for å endre vedtakets innhold. Av samme grunn som Eckhoff og Smith skriver, er det etter min mening ikke tale om omgjøring, fordi meningen ikke er å endre vedtaket, men bare å skrive inn i teksten det som må være riktig tolkning. ${ }^{59}$

Dersom ordlyden er uklar, men bare ett av tolkningsalternativene gir teksten virkninger (effekt), må dette tolkningsalternativ følges. Dette må ha vært meningen fra forvaltningens side, og mottakeren kan ikke forvente noe annet. Rt-1964-256 (Lagringstillatelse) illustrerer dette poenget. Et av sakens spørsmål gjaldt tolkningen av en bensinstasjons lagringstillatelse for bensin. Tillatelsen var gitt med det forbehold at «[t]ankanlegget fjernes eller flyttes på eierens bekostning om dette av hensyn til veivesenets interesser blir forlangt, jfr. veiloven $\S 39$ og $\S 41$.» (Side 257.) Henvisningen til de to nevnte paragrafer i veiloven skapte her tvil. Paragrafene handler om fjerning av ulovlig oppførte anlegg. Spørsmålet ble da om forbeholdet ikke ga noen mulighet til å fjerne anlegget på eierens bekostning når bensinpumpene var lovlig oppførte, slik de var her. Høyesterett tolket forbeholdet som en henvisning til den fremgangsmåte som skal an-

\footnotetext{
${ }^{56}$ Samferdselsdepartementet (2006).

${ }^{57}$ Eckhoff og Smith (2018) s. 309.

${ }^{58}$ Bernt og Rasmussen (2010) s. 333.

${ }^{59}$ Eckhoff og Smith (2018) s. 309.
} 
vendes ved fjerning av ulovlige oppførte anlegg, slik at den beskrevne fremgangsmåte i paragrafene skulle gis tilsvarende anvendelse på fjerning av lovlig oppførte anlegg. Noe annet ville innebære at forbeholdet i vedtaket ikke hadde noen effekt, og det aksepterte ikke Høyesterett.

\subsubsection{Ordlydens vekt}

Ordlydens vekt er sterk, og særlig hvis den klart tilsier en bestemt tolkning. Ordlyden binder både adressaten og forvaltningen. Forvaltningen har fått muligheten til å utforme sitt vedtak, og vi må kunne anta at ordlyden er det fremste uttrykket for dens vilje. Dersom forvaltningen ville bestemme noe annet enn det som står i vedtaket, kunne den skrevet noe annet. Ordlyden skaper også direkte forventninger hos den private part. Videre er ordlyden det mest objektive momentet både forvaltningen og den private part har tilgjengelig.

Jeg vil her vise to tydelige eksempler på den vekt Høyesterett ofte gir ordlyden. Eksemplene viser både ordlydens vekt overfor forvaltningens forutsetninger og overfor sterke reelle hensyn.

I Rt-1930-1305 (Laererlønn I), som er omtalt ovenfor i punkt 4.3, var spørsmålet som nevnt hvordan en beslutning fra bystyret i Kongsvinger om lønnsøkning for lærere skulle tolkes. En lærer mente han som følge av vedtaket hadde krav på høyere lønn enn kommunen ville gi han. I vedtaket var det både gitt $\varnothing$ kning av den faste lærerlønnen og et såkalt «dyrtidstillegg». Sistnevnte inneholdt etter ordlyden en tidsbegrensning, mens førstnevnte ikke gjorde det. Istedenfor å gi forvaltningen medhold etter dens forutsetninger om at begge deler var tidsbegrenset, la Høyesterett avgjørende vekt på at ordlyden bare hadde en tidsbegrensning for dyrtidstillegget, og ikke for den faste lærerlønnen.

I Rt-1957-375 (Konsesjonsvilkår), som jeg redegjorde for i punkt 5.2.2, tilsa vedtakets ordlyd «arbeiderne» at det bare var arbeiderne som skulle skaffes legehjelp. I motsatt retning trakk formålsbetraktninger om at også arbeidernes familier, funksjonærene og funksjonærenes familier ble skaffet legehjelp, slik mindretallet hevdet (se nærmere i punkt 5.12.2). Høyesteretts flertall la imidlertid avgjørende vekt på ordlyden.

\subsection{Felles tekstforståelse}

Fra avtaleretten kjenner vi betydningen av en felles partsoppfatning. Dersom det kan bevises at partene på avtaletidspunktet hadde en felles forståelse av innholdet i avtalen som avviker fra en alminnelig forståelse av ordlyden, legges denne felles forståelsen til grunn, se for eksempel Rt- 
2002-1155 (side 1159). ${ }^{60}$ Spørsmålet i dette punktet er om det samme gjelder for enkeltvedtak dersom det foreligger en felles tekstforståelse mellom forvaltningsorganet og den private part.

I et enkeltvedtak er det bare den private part som er «part». Forvaltningsorganet er ikke «part». Uttrykket «felles partsoppfatning» blir derfor misvisende for enkeltvedtak. Det kan også lede tanken mot at det er to likestilte parter som sammen blir enige om innholdet. Det er ikke riktig. Selv om det kan foreligge forhandlinger i forkant, er det likevel forvaltningen som ensidig utformer og fatter vedtaket. Uttrykket «felles tekstforståelse» er derfor bedre.

Knoph mente en felles tekstforståelse ikke kunne gå foran vedtakets ordlyd. ${ }^{61}$ Dette kan det være flere grunner til. For det første, som Knoph skrev, ville senere ansatte i forvaltningen måtte forholde seg til noe annet enn den teksten de selv kan lese i vedtaket. ${ }^{62}$ Det kan derfor oppstå problemer for forvaltningen ved at det blir vanskelig å holde styr på hva som er innholdet av de ulike vedtakene.

For det andre har en del vedtak betydning overfor andre enn den som er part i vedtaket. Deres forutberegnelighet avhenger av tilgjengelige momenter. Et godt eksempel er reguleringsplaner, som ikke bare vil gjelde overfor eierne i et visst område i dag, men også for senere kjøpere og andre. ${ }^{63}$ Overfor sistnevnte gruppe kan slike reguleringsplaner bli ansett som forskrifter, ${ }^{64}$ men fordi det er enkeltvedtak overfor de opprinnelige eierne er det tale om tolkning av enkeltvedtak.

Til tross for disse motargumentene er det i høyesterettspraksis likevel klare spor av at en felles tekstforståelse er relevant og vektig, men kun i saker hvor vedtaket ikke har betydning for andre enn den som er part i vedtaket. Dette innebærer at Høyesterett synes å støtte argumentasjonen om at en felles tekstforståelse ikke er relevant for vedtak med betydning for flere enn den som er part i vedtaket. Derimot virker Høyesterett mindre opptatt av problemene forvaltningen kan få med å holde styr på felles tekstforståelser som avviker fra en alminnelig tolkning. Tre høyesterettsdommer er her interessante.

Den første er plenumsdommen Rt-1931-1138 (Vinmonopolet). Saken handlet, som tidligere nevnt, om Vinmonopolets konsesjon innskrenket Stortingets mulighet til senere å pålegge kommuneskatt til Vinmonopolets aksjonærer. Høyesterett konstaterte at det ikke var noen forutsetning mellom partene at det ikke kunne pålegges kommuneskatt. Det kunne ikke Høyesterett

\footnotetext{
${ }^{60}$ Se også Høgberg (2006) s. 96.

${ }^{61}$ Knoph (1927) s. 18.

${ }^{62}$ Knoph (1927) s. 18.

${ }^{63}$ Aanerud (2017) s. 111-172 punkt. 3.2.3 mener en felles tekstforståelse ikke har betydning for reguleringsplaner.

${ }^{64}$ Innjord (2010) s. 35-36.
} 
finne st $\varnothing t t e$ for $\mathrm{i}$ verken forarbeidene eller forhandlingene mellom Vinmonopolet og statens representanter (side 1139-1140). Dette indikerer at dersom en slik felles forutsetning om forståelsen av konsesjonen kunne bevises, ville det vært relevant - og kanskje avgjørende.

Den andre dommen er Rt-1932-561 (Anleggsarbeid). Et selskap hadde fått konsesjon til å utføre en type elektrisk arbeid. I konsesjonen sto det at dersom det offentlige finner det nødvendig å ha politioppsyn i anledning «arbeidenes utførelse», plikter selskapet å betale for det. Et spørsmål var da hvilken type arbeid som var omfattet av ordet «arbeidenes». Høyesterett uttalte her på side 562 at «[p]artene er enige om at «arbeider» betegner anleggsarbeider» (ordet «arbeider står strengt tatt ikke i tillatelsen, men det fremgår av sammenhengen at Høyesterett sikter til «arbeidenes»). Høyesterett fremholdt altså denne felles enigheten om tekstforståelsen, og lot denne forståelsen være avgjørende for tolkningen av hvilket arbeid som falt inn under konsesjonsbestemmelsen. Deretter ble spørsmålet for Høyesterett om slikt arbeid var utført, og det ble funnet bevist.

Den tredje dommen er Rt-1972-1050 (Ekspropriasjonstillatelse II). Her var spørsmålet om sjøgrunnen utenfor et landområde måtte anses omfattet av et ekspropriasjonsvedtak. Det var flere grunner til at Høyesterett konkluderte med at sjøgrunnen ikke var omfattet, men det som er interessant i denne sammenheng er uttalelsen om at Høyesterett ikke kunne finne noen felles forståelse som tilsa dette:

«Jeg finner ikke grunn til å gå inn på de forhandlinger mellom partene som gikk forut for ekspropriantens søknad til departementet. Jeg begrenser meg til å si at etter min mening kan man ikke av dem utlede noen gjensidig bindende forutsetning om hva en eventuell senere ekspropriasjon skulle bygge på med hensyn til sjøgrunnen.» (Side 1053) (min kursivering).

Det kursiverte indikerer igjen at en felles tekstforståelse kunne hatt betydning.

Videre har Sivilombudsmannen i sak 2015/3270 og sak 2015/3275 (felles uttalelse) uttalt at felles enighet om tekstens betydning kan være et relevant tolkningsmoment $\mathrm{i}$ «tvilstilfeller». ${ }^{65}$ Om forståelsen av et fredningsvedtak uttalte Sivilombudsmannen følgende: «Ombudsmannen vil for egen del tilføye at enighet ikke uten videre kan utvide eller tre i stedet for eksisterende fredningsvedtak. Enighet vil i tvilstilfeller kunne være et tolkningsmoment ved fastleggelsen av hvor langt et fredningsvedtak rekker». Sivilombudsmannens forutsetning om at det må være tale om «tvilstilfeller» bør det ikke legges for mye i. Dersom det foreligger klare beviser på at forvaltningen og parten var enige om en felles forståelse på vedtakstidspunktet, bør en slik felles

\footnotetext{
${ }^{65}$ Sivilombudsmannen (2017).
} 
forståelse legges til grunn selv om ordlyden gir uttrykk for noe annet - så lenge vedtaket ikke har betydning for andre.

I juridisk litteratur har betydningen av en felles tekstforståelse støtte hos Huser, som hevder at «det i det lange løp trolig kunne virke demoraliserende både på publikum og forvaltningen, dersom en slik «enighet» ikke skal ha rettslig relevans». ${ }^{66}$ Han stiller seg kritisk til Knophs argumentasjon. ${ }^{67}$

Etter dette er det etter mitt syn ikke tvilsomt at en felles tekstforståelse kan ha betydning. Dette bidrar til å skape forutberegnelighet for både den private part og forvaltningen. Så lenge vedtaket ikke har betydning for andre, må dette veie tungt. Når det har betydning for andre, tilsier hensynet til deres forutberegnelighet at de utfra tilgjengelige kilder kan finne frem til vedtakets innhold. De tre nevnte høyesterettsdommer og saken fra Sivilombudsmannen gjaldt da heller ikke vedtak med betydning for andre berørte. Det må altså skilles etter typen vedtak for å avgjøre om en felles tekstforståelse er relevant for tolkningen. Dersom man først er på et område hvor det er relevant, er det grunn til å tro at vekten er så sterk at det kan gå foran vedtakets ordlyd.

\subsection{Om vedtaket er til gunst eller ugunst}

Det kan stilles spørsmål ved om det er forskjell på tolkningen av vedtak til gunst for og vedtak til ugunst for den private part. Castberg hevdet at vedtak til ugunst må underlegges en «streng fortolkning», ${ }^{68} \mathrm{i}$ den forstand at tvil om tolkningen av ugunstige vedtak skal løses i favør av den private part. Samtidig fremhever Andersen og Boe at det kan være grunn til å tolke vedtak til gunst i den private parts favør. ${ }^{69}$

Jeg skal i inneværende punkt drøfte om det utgjør et selvstendig tolkningsmoment om vedtaket er til gunst eller ugunst for den private part. Jeg tar først for meg argumentasjonen om vedtak til ugunst, deretter argumentasjonen om vedtak til gunst.

Ifølge Castberg følger det av legalitetsprinsippet at vedtak til ugunst må tolkes i favør av den private part. ${ }^{70}$ Han gir imidlertid ingen nærmere begrunnelse for sitt syn, og jeg finner det vanskelig å forstå argumentet. Enkeltvedtak må holde seg innenfor de rammer hjemmelsloven og

\footnotetext{
${ }^{66}$ Huser (1983) s. 410.

${ }^{67}$ Huser (1983) s. 479.

${ }^{68}$ Castberg (1955) s. 150.

${ }^{69}$ Andersen (1930) s. 258 og Boe (2010) s. 264. Andersens bok gjelder dansk forvaltningsrett, men det har likhetstrekk med norsk forvaltningsrett.

${ }^{70}$ Castberg (1955) s. 150.
} 
andre rettsregler setter. Hjemmelsloven kan derfor være et moment ved tolkningen av vedtaket (se punkt 5.7). Men dersom tolkningsalternativene holder seg innenfor disse rammene er legalitetskravet oppfylt. Dermed kan ikke legalitetsprinsippet begrunne at man blant to (eller flere) tolkningsalternativer som begge eller alle har tilstrekkelig hjemmel, skal velge det alternativet som er «mildest» for den private part. Det ville være konsekvensen av et generelt moment om at tolkningstvil skal løses i favør av den private part. Så lenge kravet til lovhjemmel er oppfylt for begge/alle tolkningsalternativer, kan altså ikke legalitetsprinsippet begrunne dette.

Et annet mulig argument til støtte for Castbergs syn er at ugunstige vedtak vil være byrdefulle å overtre. Av den grunn skulle man være forsiktig med å velge det tolkningsalternativ som vil være til skade for den private part. Det er imidlertid ikke bare overtredelse av vedtak til ugunst som kan være byrdefullt for den private part. Selv om den som mottar en forurensningstillatelse har fått et vedtak til gunst, vil overtredelse av bestemmelser i vedtaket kunne føre til straff, slik som i HR-2017-821-A (Marine Harvest). Det kan med andre ord være like byrdefullt å overtre et vedtak til gunst. Samtidig behøver ikke overtredelse av et vedtak til ugunst å være særlig byrdefullt, for eksempel om man ikke retter seg etter pålegg om å flytte hekken sin.

Det er heller ikke lett å finne spor av at et slikt tolkningsmoment har spilt noen rolle i rettspraksis. Det er klart at domstolene i den enkelte sak legger vekt på ulike reelle hensyn, slik som konkret rimelighet, men dette hensynets vekt synes ikke å være avhengig av om vedtaket er til gunst eller ugunst.

I denne sammenheng er det interessant å sammenligne med tolkning av lover som pålegger byrder for den private part. I ulike saker har det blitt anført at tvil om lovtolkningen skal komme den private part til gode. Et slikt prinsipp har imidlertid ikke støtte i rettspraksis, heller ikke i strafferetten. Dersom det først foreligger en lovbestemmelse som handlingen omfattes av, vil ikke tvil om bestemmelsen også kan forstås på andre måter komme tiltalte til gode. ${ }^{71}$ I straffesaken i Rt-2012-387 (Stedatter) gjentok Høyesterett dette:

«Som sagt er det ikke spørsmål om å gå utenfor ordlyden i denne saken, men - ut fra alminnelig rettskildebruk - å velge en av to tolkninger som ordlyden gir grunnlag for. Det kan ikke oppstilles et prinsipp om at tvil om rettsanvendelsen skal løses til fordel for tiltalte, jf. Rt-1984-91 på side 92.» (Avsnitt 22.)

\footnotetext{
${ }^{71}$ Det er en viss diskusjon i juridisk teori mellom Andenæs (2016) s. 115 og Høgberg (2007) s. 20-36, men Høgbergs innvendinger er skrevet før høyesterettsdommen fra 2012. Riktignok påpeker han at det er tale om en rettskilderegel, ikke en rettsregel, og at man ikke kan slutte fra høyesterettspraksis på samme måte i slike spørsmål, se min drøftelse av disse spørsmål i punkt 1.3.
} 
Det samme har blitt lagt til grunn ved tolkning av skatte- og avgiftslover. I Rt-2014-1281 uttaler Høyesterett at:

«Legalitetsprinsippet får anvendelse generelt der staten gjør inngrep overfor den enkelte, og krever hjemmel i lov, jf. Grl. § 113. Det innebærer at lovens ordlyd står sentralt ved tolkningen. Men tolkningstvil må løses ut fra hva som er best i samsvar med en avveining av samtlige rettskildefaktorer og som sikrer tilstrekkelig klarhet og forutsigbarhet for borgerne. Et prinsipp om at tolkningstvil i en sak skal løses i borgernes favør, vil lett kunne slå ut motsatt for andre avgiftspliktige $\mathrm{i}$ andre sammenhenger, og er neppe egnet som noen god rettesnor.» (Avsnitt 48.)

For lover som pålegger byrder gjelder det med andre ord ikke et prinsipp om at tolkningstvil skal løses i favør av den private, så lenge begge alternativer ligger innenfor hjemmelens rammer. Det er vanskelig å se hvorfor noe annet skulle gjelde for enkeltvedtak til ugunst for den private part.

For vedtak til gunst, argumenterte Andersen for at uklarhet må gå ut over forvaltningen. ${ }^{72}$ Også Boe fremhever at det kan «hevdes at forvaltningen er nærmest til å bære risikoen for at den ikke har klart å uttrykke seg så presist som tanken var», men det er litt uklart hva Boe konkluderer med. ${ }^{73}$ Til Andersens fremstilling påpekte Castberg at dette ikke kan gjelde som en alminnelig regel. ${ }^{74} \mathrm{Jeg}$ har heller ikke funnet spor av et slikt moment i høyesterettspraksis. Det er også vanskelig å se hvorfor forvaltningen skulle være nærmere til å bære risikoen for ikke å ha uttrykt seg presist ved vedtak til gunst enn ved vedtak til ugunst. Når så noe slikt ikke gjelder ved vedtak til ugunst kan det etter mitt syn heller ikke gjelde ved vedtak til gunst.

Etter dette synes det ikke å være grunnlag for å hevde at det går et skille mellom tolkningen av vedtak til gunst og til ugunst. Dette utgjør altså ikke et selvstendig tolkningsmoment. Det er mer sentralt hvor betydningsfullt vedtaket er for den private part, uavhengig av om det er til gunst eller ugunst. I begge typesituasjoner kan det foreligge sterke rimelighetshensyn som kan tale i favør av en tolkning i tråd med den private parts syn. Det er klart at slike hensyn er relevante, se nærmere i punkt 5.12 om reelle hensyn.

\footnotetext{
${ }^{72}$ Andersen (1930) s. 258.

${ }^{73}$ Boe (2010) s. 264.

${ }^{74}$ Castberg (1955) s. 151.
} 


\subsection{Vedtakets begrunnelse}

De aller fleste enkeltvedtak begrunnes, ettersom dette er et krav i fvl. § 24 første ledd første punktum. Fvl. § 25 stiller minstekrav til begrunnelsens innhold, men ofte er begrunnelsen grundigere enn lovens krav.

Begrunnelsen har utvilsomt stor betydning for tolkningen og det er det flere grunner til. ${ }^{75}$ Den kan for det første ha utdypende forklaringer om meningen med vedtaksslutningen. For det andre kan begrunnelsen inneholde presiseringer som begrenser eller utfyller slutningen. For det tredje kan den gi opplysninger om faktiske forhold av betydning for tolkningen.

Begrunnelsen er ikke en del av selve vedtaksslutningen, men har nær tilknytning til vedtaket fordi den som hovedregel skal gis samtidig som vedtaket, jfr. fvl. § 24 første ledd annet punktum. Ettersom den gis samtidig, vil begrunnelsen kunne gi den private part minst like store forventninger om forståelsen av vedtaket som selve vedtaksslutningen. Dette gjelder særlig hvis begrunnelsen klart tilsier en bestemt tolkning og vedtaksslutningen er uklar. I tillegg rekker ikke den private part å få en berettiget forventning om at vedtaket skal forstås på noen annen måte enn det begrunnelsen gir uttrykk for. Dette tilsier at begrunnelsen skal ha sterk vekt som tolkningsmoment.

Tolkningen av et enkeltvedtak kan imidlertid også ha betydning for andre berørte enn den som er part i vedtaket. Disse blir ikke nødvendigvis gjort umiddelbart kjent med begrunnelsen, og det er heller ikke sikkert at begrunnelsen er lett tilgjengelig i ettertid. For eksempel kan det tenkes at begrunnelsen for en byggetillatelse ikke blir gjort kjent for utbyggerens nabo. I slike tilfeller kan det være grunn til å tillegge begrunnelsen mindre vekt, men den må fortsatt være relevant.

Jeg har ikke funnet noen høyesterettsdom hvor det uttrykkelig vises til vedtakets begrunnelse, men det er vanskelig å se for seg at Høyesterett ikke ville tatt begrunnelsen i betraktning. Høyesterett vektlegger jo andre synbare forutsetninger hos forvaltningen. I tillegg minner begrunnelsens funksjon for vedtaket om domspremissenes funksjon i dommer. Ved tolkning av dommer tillegger Høyesterett domspremissene betydelig vekt, som vist ovenfor i punkt 2. Det er nok derfor grunn til å tro at Høyesterett vil vektlegge begrunnelsen ved tolkningen av enkeltvedtak.

\footnotetext{
${ }^{75}$ Boe (2010) s. 263 mener også dette er tolkningsmoment.
} 
I det daglige løser begrunnelsen svært mange tolkningsspørsmål uten at det oppstår noen tvist om tolkningen. ${ }^{76}$ Det kan være forklaringen på at det er vanskelig å finne høyesterettsdommer som omtaler begrunnelsen. Dersom noe er omtalt i begrunnelsen, er det nok naturlig at dette ofte blir lagt til grunn som en del av vedtakets innhold. Dermed forsvinner potensiell tvist om tolkningen.

Flere eksempler kan vise begrunnelsens betydning i praksis. Et eksempel er en nylig gitt skjenkebevilling til Odeon kino i Oslo. ${ }^{77}$ Vedtaksslutningen er relativt kort. Der står det kun at søknaden innvilges og hvilke kinosaler hvor alkohol vil være lovlig. Begrunnelsen inneholder derimot flere presiseringer fra forvaltningen, som fremstår som helt klare plikter for parten. For eksempel inneholder begrunnelsen skjenkebevillingens lengde: «Byråden vil fremheve at en innvilgelse er kun ut denne skjenkeperioden (til 30.09.2020)» (punkt 2.1 siste avsnitt). ${ }^{78}$ Et annet eksempel er at den stiller krav til alderskontrollen: «Det er viktig at kontrollen med alder skjer ved ankomst til andre etasje» (punkt 2.1 nest siste avsnitt). Formuleringen av disse punktene i begrunnelsen gir dem et klart preg av å være en del av vedtakets innhold, og det er vanskelig for Odeon kino å forstå dette annerledes.

Et annet eksempel er vedtakene til Skatteklagenemnda, hvor det ofte bare angis at inntekten $\varnothing k$ kes eller reduseres med et visst beløp eller at det pålegges tilleggsskatt i prosent av et visst beløp. ${ }^{79}$ For å finne hva inntektsøkningen/reduksjonen eller tilleggsskatten gjelder, må man gå til begrunnelsen. Et inntektstillegg på for eksempel $100000 \mathrm{kr}$ kan utgjøre summen av økning og reduksjon på flere ulike poster, slik at det for eksempel er økning på en gevinst, reduksjon av en annen, enkelte reduserte fradrag og enkelte $\emptyset$ kte fradrag. Skal man finne hvilke poster som er økt og redusert, og dermed hva skattevedtaket går ut på, må man altså se på begrunnelsen. Dette kan ha betydning for om hele vedtaket skal angripes eller bare enkelte av postene. Nettopp fordi skattyter leser begrunnelsene oppstår det nok sjeldent tvister om tolkningen av skattevedtakene.

Vi ser altså at begrunnelsen er praktisk viktig for tolkningen av enkeltvedtak, og det er sterke grunner til å vektlegge den. Begrunnelsen må derfor være et sentralt tolkningsmoment med betydelig vekt.

\footnotetext{
${ }^{76}$ Hopsnes (2017) s. 271 påpeker også dette.

${ }^{77}$ Byrådet (2018).

${ }^{78}$ Lengden følger også av alkoholloven $\S 1-6$.

${ }^{79}$ Skatteetaten. «Skatteklagenemnda». 2018.
} 


\subsection{Søknaden}

Når det foreligger en søknad forut for vedtaket, vil denne kunne være et relevant tolkningsmoment. Dette gjelder som regel de vedtak hvor det gis en tillatelse eller et fritak fra en generell bestemmelse, for eksempel en forurensningstillatelse.

Når søknader innvilges, er det to typetilfeller av innvilgelser. Det første er hvor det i forvaltningens vedtak står at «søknaden innvilges». Da følger det direkte av vedtakets ordlyd at man må lese søknaden for å fastlegge vedtakets innhold. I mangel av nærmere presiseringer i vedtaket eller andre synbare forutsetninger, må man også anta at søknaden er innvilget i sin helhet.

Det andre tilfellet er når forvaltningen ikke direkte skriver at søknaden innvilges, men likevel fatter et vedtak som går ut på noe det er søkt om. Søknaden gir fortsatt en forutsetning for hva forvaltningen vedtar, og dette er synbart for den private part. Den private part kan ikke regne med å få noe mer eller annet enn det som er søkt om. Samtidig gir søknaden også synbare forutsetninger fra den private part til forvaltningen. Dette innebærer at dersom forvaltningen ikke presiserer at søknaden innvilges kun delvis, kan dette gå ut over forvaltningen, slik at vedtaket tolkes i tråd med den privates parts forutsetninger.

I høyesterettspraksis finnes det særlig fire avgjørelser hvor søknaden er tillagt betydning som tolkningsmoment. I den ene saken var søknaden til støtte for den private parts syn, mens i de tre andre sakene var søknaden til støtte for forvaltningens syn.

I Rt-1913-727 (Bakeri) fikk forvaltningen medhold i at vedtaket måtte tolkes i lys av søknaden. ${ }^{80}$ Søknaden gjaldt tillatelse til ombygging av et bakeri. Som vedlegg til søknaden forelå det plantegninger om høydeforholdene i rommet. Dette skapte klare forutsetninger hos forvaltningen om at ombygningen skulle skje i tråd med tegningene, selv om forvaltningen ikke ga uttrykk for dette i tillatelsens ordlyd. Etter å ha fått tillatelsen, valgte bakeriet å bygge annerledes. Høyesterett sa seg enig med forvaltningen $i$ at dette var i strid med tillatelsen, nettopp fordi det lå synbare forutsetninger i søknaden.

I Rt-1915-721 (Wahrens) var det et privat selskap som fikk medhold i at vedtaket måtte tolkes i lys av søknaden. Wahrens hadde søkt om tillatelse til tollfri import av klær. I søknaden kom det frem at Wahrens ønsket tillatelsen for den tid det tok å vurdere om slik drift var lønnsomt, noe som ville være 3 år. Departementet innvilget søknaden uten bemerkninger til den. Senere hevdet departementet at tillatelsen bare gjaldt ut budsjettåret, etter at Stortinget hadde endret

\footnotetext{
${ }^{80}$ Dommen er ikke inntatt på Lovdata.
} 
tolltariffen. Departementet anførte også at det bare hadde kompetanse til å gi tillatelse ut budsjettåret (se nærmere om dette i punkt 5.7). Høyesterett la derimot avgjørende vekt på at dette ikke var noe Wahrens burde ha forstått og at departementet ikke hadde bemerkninger til søknaden. De synbare forutsetninger Wahrens hadde gitt uttrykk for gjennom søknaden fikk altså stor vekt.

Et tredje eksempel på søknadens betydning er Rt-1961-297 (Glacier Blue). Kjøpmannen Sundseth hadde søkt om tillatelse til å kjøpe begravelsesbil. Etter å ha fått tillatelsen og kjøpt bilen, tok han den ikke i bruk til begravelsesformål. Vegdirektoratet påla derfor Sundseth å lakkere bilen svart, hvilket han motsatte seg. Deretter avskiltet direktoratet bilen. Spørsmålet for Høyesterett var om pålegget og avskiltingen var rettmessig, og Høyesterett måtte i den forbindelse tolke vedtaket. Høyesterett viste særlig til søknaden som et moment, og anså pålegget og avskiltingen for å være rettmessig.

Den fjerde saken er Rt-1998-2011 (Mongstad). Statoil hadde fått forurensningstillatelse til utslipp på et oljeraffineri. Tillatelsen ble etter statens syn overtrådt, og Statoil ble ilagt foretaksstraff. De faktiske forurensningsspørsmålene er ikke lett tilgjengelige, men det rettslig interessante er hvordan Høyesterett sluttet fra søknaden til sin konklusjon. Høyesterett uttalte at «[i]følge den innvilgede søknad var det "renset vann" som skulle føres til sikringsbassenget. Jeg forstår derfor konsesjonen slik at ...» (side 2018). Det var altså en klar sammenheng mellom forståelsen av søknaden og hvordan Høyesterett tolket enkeltvedtaket.

I alle fire sakene fikk søknaden betydelig vekt ved tolkningen. Dette må gjelde generelt. Søknaden gir uttrykk for synbare forutsetninger fra søkeren, samtidig som den skaper synbare forutsetninger for forvaltningens vedtak. På samme måte som jeg har drøftet om begrunnelsen som tolkningsmoment, kan søknaden likevel få mindre vekt om det er andre som berøres av vedtaket og søknaden er utilgjengelig.

\subsection{Hjemmelen for vedtaket}

I punkt 5.2.2 om ordlydsslutninger viste jeg hvordan hjemmelsloven kan få betydning ved at ord og uttrykk i vedtaket ofte har samme betydning som tilsvarende ord og uttrykk i hjemmelsloven. I inneværende punkt skal jeg ta opp hjemmelsloven som grense for vedtakets innhold, noe som også kan få betydning for tolkningen av vedtaket.

Når jeg her viser til hjemmelsloven, herunder også hjemmelsforskrifter, mener jeg loven ferdig tolket. Lovens forarbeider og andre momenter som fastlegger lovens innhold vil dermed indirekte ha betydning for tolkningen av enkeltvedtak, men jeg anser dette for å være en del av hjemmelsloven som tolkningsmoment. 
Forvaltningens enkeltvedtak krever hjemmel i lov eller annet rettsgrunnlag for å være gyldig overfor den private part. I dette ligger det også at vedtaket som den klare hovedregel ikke kan være mer omfattende enn rettsgrunnlaget gir kompetanse til. Dette må være et relevant moment ved tolkningen av enkeltvedtak, slik at man fors $\varnothing$ ker å forene tolkningsresultatet med det rettsgrunnlaget gir kompetanse til. Det har formodningen mot seg at forvaltningen skulle ha fastsatt noe den ikke hadde kompetanse til. Dersom det likevel ikke er mulig å forene tolkningsresultatet med det rettsgrunnlaget gir kompetanse til, er alternativet ofte at vedtaket blir kjent helt eller delvis ugyldig. Det er imidlertid ikke gitt at dette blir resultatet dersom det medfører store negative konsekvenser for en godtroende part, se et mulig eksempel nedenfor. ${ }^{81}$

At kompetansegrunnlaget er relevant ved tolkningen er ikke spesielt for enkeltvedtak. Det samme momentet gjelder også ved tolkning av lover. Det har formodningen mot seg at Stortinget har vedtatt en lov som strider mot Grunnloven, og en potensiell grunnlovsstrid vil ofte føre til en innskrenkende tolkning av lovens ordlyd.

Det har videre blitt hevdet $\mathrm{i}$ juridisk teori at kompetansegrunnlaget er sentralt ved tolkning av enkeltvedtak. Castberg mente det er en presumpsjon imot at forvaltningen har gjort noe den ikke har lov til eller som ville være rettsstridig. ${ }^{82}$ Også Hagstrøm mente at lovhjemmelen har betydning for tolkningen av enkeltvedtak. ${ }^{83}$

Et eksempel på at Høyesterett anvender lovhjemmelen ved tolkningen av enkeltvedtak er Rt1972-32 (Ekspropriasjonstillatelse I). Sakens spørsmål var om sjø- og elvegrunnen utenfor et landområde var omfattet av et ekspropriasjonsvedtak. Høyesterett la her vekt på flere forhold. Først og fremst måtte man vanligvis regne med at sjø- og elvegrunnen knytter seg til landområdet, og at grunneierne ikke lenger ville eie landområde som grenset til den omtvistede sjø- og elvegrunnen. Dernest var lovhjemmelen et moment. Høyesterett uttalte følgende i forbindelse med den konkrete tolkningen av tillatelsen: «At bygningslovens $\S 36 \mathrm{nr} .1$ i og for seg gir adgang til å la en ekspropriasjon av landområder også omfatte tilstøtende sjø- og elvegrunn, kan jeg ikke finne tvilsomt.» (Side 37.) Poenget med å vise at bygningsloven ga hjemmel til å ekspropriere også tilstøtende sjø- og elvegrunn må være fordi det er et relevant tolkningsmoment. Noen avgjørende vekt fikk nok ikke momentet her, men dersom bygningsloven ikke hadde hjemlet ekspropriasjon av sjø- og elvegrunnen, ville det antakelig vært avgjørende i motsatt retning.

\footnotetext{
${ }^{81}$ Eckhoff og Smith (2018) s. 465-466.

${ }^{82}$ Castberg (1955) s. 150.

${ }^{83}$ Hagstrøm (2011) s. 691.
} 
En sak fra lagmannsretten støtter sistnevnte synspunkt. I LB-2002-1303 (Fisketillatelse) hadde et selskap fått inndratt verdier tilsvarende hva fiskeridirektoratet mente var overfisket. Selskapet hevdet at fisketillatelsen innebar dispensasjon fra den opprinnelige kvotetildelingen. Lagmannsretten uttalte at dette åpenbart ikke hadde vært meningen med vedtaket og at «direktoratet hadde i 1997 heller ikke hjemmel for å dispensere fra reglene om kvotetildeling». Dette fikk betydning for tolkningen av vedtaket.

Videre var lovhjemmelen sentral i Rt-2010-850 (Koppang), som gjaldt straff for overtredelse av et fredningsvedtak. Etter vedtaket var bygningen «Barfrøstue» tatt inn på en liste over «bygninger m.v.» som skulle fredes. Tiltalte hadde tatt ut inventar fra denne bygningen, og et av sakens spørsmål var om inventaret var omfattet av fredningsvedtaket. Det var klart at hjemmelsloven (bygningsfredningsloven fra 1920) ikke hjemlet fredning av l $\phi s t$ inventar, men det var uklart om den hjemlet fredning av fast inventar. Høyesterett uttalte at «[s]pørsmålet om gjenstandene er fredet, blir da i realiteten et spørsmål om å fastlegge hjemmelslovens rekkevidde.» (Avsnitt 11.) Dersom loven hjemlet fredning, ville det åpne for at vedtaket omfattet inventaret. Dersom loven ikke hjemlet fredning, ville det tale for at vedtaket ikke omfattet inventaret. Hjemmelsloven ble altså brukt som et tolkningsmoment ved fastleggelsen av vedtakets innhold. Høyesterett kom til at loven ga hjemmel til å frede fast inventar. Etter en nærmere vurdering konkluderte Høyesterett også med at deler av det faste inventaret var omfattet.

Rt-1915-721 (Wahrens) kan på den annen side gi et eksempel på at kompetansebegrensinger hos forvaltningen ikke alltid er avgjørende. Som redegjort for i punkt 5.6, var spørsmålet om en tillatelse gjaldt for de tre årene det var søkt om eller om den bare gjaldt ut budsjettåret. Departementet anførte at det kun hadde kompetanse til å gi tillatelse ut budsjettåret, men søknaden var innvilget uten bemerkninger om en slik tidsbegrensning. Høyesterett uttalte at Stortingsuttalelser gikk i retning av at departementet hadde kompetanse til å gi en treårig tillatelse, men påpekte at dette uansett ikke kunne gå utover Wahrens (side 722). Dette indikerer at en eventuell kompetansebegrensning ikke ville hindret en tolkning i tråd med Wahrens syn, men det kan selvsagt ikke utelukkes at konklusjonen ville blitt annerledes om det var klart i strid med kompetansen.

Disse dommene viser at kompetansegrunnlaget tillegges stor vekt. Det skal en del til før domstolene vil tolke et vedtak i strid med forvaltningsorganets kompetanse. En slik tolkning vil ofte medføre at vedtaket er helt eller delvis ugyldig, men den svært gamle dommen Rt-1915-721 (Wahrens) er et eksempel på at det motsatte kan tenkes. 


\subsection{Annen rett enn hjemmelsloven}

Annen rett enn hjemmelsloven kan også gi tolkningsmomenter. For det første vil annen rett kunne sette grenser på linje med hjemmelsloven for hvordan ord og uttrykk kan forstås for at ikke enkeltvedtaket skal bli ugyldig. Det vil ha formodningen mot seg at et enkeltvedtak strider mot også annen rett enn hjemmelsloven, og en upresis ordlyd vil det være naturlig å tolke i overenstemmelse med annen rett. Alternativet er ofte hel eller delvis ugyldighet.

Grunnloven, EMK, EØS-avtalen, andre folkerettslige forpliktelser, andre lover og ulovfestet rett vil kunne sette slike grenser. For eksempel kan ikke en byggetillatelse tolkes slik at den gir rett til at det under byggingen forurenses i strid med forurensningsloven. Selv med tillatelse etter én lov, vil det fortsatt kunne være nødvendig med andre tillatelser etter andre lover, noe Høyesterett understreket i Rt-2012-18 (Kistefos) avsnitt 75.

For det andre kan annen rett innenfor disse grensene gi holdepunkter for presisering av ord og uttrykk i enkeltvedtaket. Hvis et vedtak bruker uttrykk som «aksjeselskap», «ektepakt» eller «salg», er det naturlig at uttrykkene forstås slik de vanligvis brukes i annen norsk rett. ${ }^{84}$

For eksempel kan det i en konsesjon være forbud mot salg av virksomheten. Et spørsmål som da kan reise seg er om det foreligger et «salg» hvis selskapet som har fått konsesjonen fusjonerer med et annet selskap. Da vil Høyesteretts dom i HR-2017-1664-A fra et helt annet rettsområde være relevant. Her kom Høyesterett til at fusjonering av to selskaper ikke var et «salg» etter en avtaleklausul hvor «salg» ville utløse forkjøpsrett av en eiendom hos det ene selskapet. Denne dommen fra et annet rettsområde vil dermed kunne utgjøre et viktig tolkningsmoment også for hva «salg» i konsesjonen betyr.

Høyesterettspraksis viser betydningen av dette momentet. I Rt-1972-32 (Ekspropriasjonstillatelse I), nevnt ovenfor, var spørsmålet i saken om sjø- og elvegrunnen utenfor et landområde var omfattet av et ekspropriasjonsvedtak. Et av de sentrale momenter Høyesterett trakk frem var at:

«Det er en velkjent regel at de tilstøtende områder under vann følger stranden, når ikke annet er særskilt bestemt. ... Også ved ekspropriasjon vil det være naturlig å regne med at retten over sjø- og elvegrunn følger det tilstøtende landområde som eksproprieres, med mindre noe annet klart går frem av forholdene.» (Side 36.)

\footnotetext{
${ }^{84}$ Avsnittet er inspirert av Zimmer (2018) s. 51-53 om skattelovgivningens forhold til privatrettslige begreper.
} 
Høyesterett viser her til hva som er alminnelig tingsrett utenfor ekspropriasjonslovgivningen. Deretter fortsetter Høyesterett:

«I samsvar med den samhørighet mellom strand og tilstøtende vann og grunn under vannet som er vanlig etter norsk rett, antar jeg at når ikke annet er sagt eller går frem av forholdene, vil det i alminnelighet være naturlig å forstå både en ekspropriasjonss $\emptyset \mathrm{knad}$ og en tillatelse slik at når det er tale om land med strand, er det meningen også at tilstøtende sjø- og elvegrunn skal følge med.» (Side 37.)

Igjen viste Høyesterett til hva som er alminnelig norsk tingsrett. Det spilte altså en rolle for tolkningen av ekspropriasjonsvedtaket hvordan forholdet mellom et landområde og sjø- og elvegrunnen vanligvis henger sammen i alminnelig norsk tingsrett.

Dette viser at Høyesterett vektlegger annen rett som tolkningsmoment og at annen rett vil kunne få stor vekt.

\subsection{Vedtakets forarbeider, forhandlinger og annen forhistorie}

Vedtakets forarbeider, forhandlinger og annen forhistorie kan være andre relevante tolkningsmomenter. Det er uklare grenser mellom disse momentene, men poenget her er å få frem at ulike sider av forhistorien bak vedtaket er relevant ved tolkningen. Jeg skal først si noe om hva jeg legger i disse uttrykkene, før jeg deretter ser på deres betydning som tolkningsmoment.

Med «forarbeider» sikter jeg til ulike dokumenter utformet av forvaltningen i forkant av et vedtak. For eksempel vil det ved utformingen av en reguleringsplan foreligge planforslag, konsekvensutredninger, protokoller fra ulike møter, høringer og så videre.

Med «forhandlinger» sikter jeg til diskusjon mellom forvaltningen og den private part i forkant av vedtaket, uten at det er tale om å inngå en avtale. Dette kan være i form av forhandlingsmøter, brev, epost og så videre. Særlig innenfor olje- og gass-sektoren er det aktuelt med forhandlinger før et vedtak fattes av forvaltningen.

Med «annen forhistorie» sikter jeg til en løsere gruppe av andre faktiske omstendigheter. Søknaden er en del av forhistorien, men er særskilt behandlet i punkt 5.6. Poenget her er å nevne at andre deler av forhistorien kan tas i betraktning. Det er neppe hensiktsmessig med noen skarp avgrensning av hvilke faktiske omstendigheter som kan kaste lys vedtaket. Det vil selvsagt ha betydning for vekten om omstendighetene har gitt seg utslag i synbare forutsetninger, men noen klar avgrensning av irrelevante momenter er ikke nødvendig. 
Vekten av disse tre typer momenter er varierende. Vekten vil særlig bero på hva det er mulig å utlede og på hvor synlig dette er for den private part og eventuelt andre berørte.

Når det gjelder forarbeidsdokumenter vil tilgjengeligheten variere. Når noe er utilgjengelig for den private part må vekten være lav. Boe mener det samme og hevder at forarbeidene må spille en «mindre rolle», både fordi de som regel er utilgjengelige og på grunn av varierende kvalitet. ${ }^{85}$ Mer treffende er det kanskje å si at de må spille en mindre rolle hvis de er utilgjengelige og ikke gir klare føringer. Dersom de først er offentlige og forvaltningens forutsetninger lar seg utlede, kan de spille en større rolle.

Forhandlinger vil begge sider alltid være kjent med. Det som her fremkommer av forutsetninger hos enten parten eller forvaltningen bør kunne vektlegges, hvis ikke den andre tydelig har motsatt seg dette. En slik tydeliggjøring kan selvsagt skje i vedtakets ordlyd eller begrunnelse. De forutgående forhandlinger kan derfor ha stor vekt ved tolkningen, men også vekten av dette momentet reduseres dersom vedtaket har betydning for tredjemenn.

Når det gjelder andre faktiske omstendigheter forut for vedtaket er det vanskelig å si mye generelt. Det mest generelle må være at slike faktorer klart nok kan spille en rolle.

En dom som belyser vektleggingen av alle de tre nevnte kategorier er Rt-1985-1355 (Phillips Petroleum). Saken gjaldt statens mulighet til å endre betalingsvilkårene for en gruppe oljeselskaper som hadde fått utvinningstillatelse i 1965. Staten forsøkte å endre vilkårene med hjemmel i en forskrift fra 1972. ${ }^{86}$ Dette reiste flere spørsmål. Ett av disse spørsmålene var hvilke bindinger som fulgte av 1965-tillatelsen. Høyesterett ville ikke ta stilling til om 1965-tillatelsen delvis skulle anses som en avtale eller om tillatelsen i sin helhet var et enkeltvedtak, men det var klart at store deler av den var et enkeltvedtak. Høyesterett kom til at vedtaket la begrensninger på statens endringsadgang. Ved tolkningen så Høyesterett på flere deler av forhistorien.

Først viste Høyesterett til forhandlingene som hadde funnet sted, hvor et av siktepunktene var «å komme frem til vilkår som oljeselskapene fant akseptable for å gå i gang med virksomhet på norsk sokkel» (side 1371). Deretter så Høyesterett på ulike utkast til utforming av tillatelsen, noe som kunne kaste lys over betydningen av de endelige formuleringer (forarbeider). For det tredje så Høyesterett på et brev fra staten til selskapet, hvor et av utkastene til tillatelsen var forklart (annen forhistorie). Dette viser at ulike former for forarbeider, forhandlinger og annen forhistorie ble vektlagt.

\footnotetext{
${ }^{85}$ Boe (2010) s. 263.

${ }^{86}$ Kongelig resolusjon av 8 desember 1972 om unders $\varnothing$ kelse etter og utnyttelse av undersjøiske petroleumsforekomster.
} 
Et annet eksempel på bruk av forarbeider som tolkningsmoment gir Rt-1957-497 (Ryddeplikt). En brukseierforening fikk konsesjon til å regulere tre områder i et vassdrag. Konsesjonen ble gitt på det vilkår at foreningen «plikter å ryddiggjøre de neddemte arealer». Det oppsto spørsmål om hvor omfattende ryddeplikten var. Foreningen mente det måtte innfortolkes begrensninger i ryddeplikten ut fra en $\varnothing$ konomisk avveining mellom verdien av fisket mot kostnadene ved rydding. Høyesterett avviste dette synspunktet, og uttalte at:

«... hverken ordlyden av konsesjonsvilkåret eller forarbeidene gir grunnlag for å innfortolke noen begrensning i ryddingsplikten ut fra en rent $\varnothing$ konomisk avveiing av reduksjonen av fiskets verdi mot meromkostningene ved en fullstendig rydding.» (Side 498) (min kursivering).

Høyesterett siktet her til konsesjonens forarbeider, og påpekte tydelig at disse forarbeidene var et tolkningsmoment. Verken forarbeidene eller ordlyden ga grunnlag for noen begrensning $\mathrm{i}$ plikten etter rent $\varnothing$ konomiske kriterier.

\subsection{Forvaltningspraksis}

Ved lovtolkning er forvaltningspraksis et relevant tolkningsmoment dersom det foreligger en «fast og konsistent» praksis, jfr. HR-2016-2017-A avsnitt 50. Spørsmålet i dette punktet er om det på tilsvarende måte kan legges vekt på forvaltningspraksis ved tolkning av enkeltvedtak.

Ved tolkning av enkeltvedtak må eventuell «forvaltningspraksis» knytte seg til praktiseringen av tidligere enkeltvedtak med samme ordlyd som det aktuelle enkeltvedtaket (tolkningsobjektet). Dersom forvaltningen har hatt en fast og konsistent praktisering av den samme ordlyden i de tidligere vedtakene, vil dette si noe om hva forvaltningen nå har ment med det aktuelle vedtaket. Denne forvaltningspraksisen kan da være et relevant tolkningsmoment. Etter mitt syn må imidlertid vekten av forvaltningspraksis bero på om praksisen er synbar for den private part.

Hvis forvaltningen for eksempel tidligere har fattet ni like byggetillatelser i et nabolag og disse har blitt praktisert på én bestemt måte, tilsier det at det tiende vedtaket forstås på samme måte. Dersom parten i det tiende vedtaket er eller burde være klar over denne praksisen, kan han ikke forvente et annet resultat, og forvaltningens forutsetninger bør derfor følges. Dersom praksisen derimot ikke var synbar for den private part, må vekten av forvaltningspraksisen være liten.

Jeg har ikke funnet rettspraksis som vektlegger forvaltningspraksis ved tolkningen av enkeltvedtak, men momentet er omtalt i juridisk teori. Boe mener forvaltningspraksis i mange tilfeller vil kunne belyse innholdet av et enkeltvedtak, men han påpeker samtidig at «[e]n ulempe med 
å legge vekt på forvaltningens presedenser er at presedenser heller ikke er lett tilgjengelige for parten.» ${ }^{87}$

Fast og konsistent forvaltningspraksis kan altså være relevant, men vekten må bero på synbarheten for den private part. Kravet til synbarhet vil ofte føre til at vekten blir liten, fordi det sjelden kan forventes at den private part kjenner til praksisen.

\subsection{Etterfølgende omstendigheter}

Etterfølgende omstendigheter er en samlekategori av ulike omstendigheter som i tid kommer etter vedtaket. Prinsipielt sett kan det være betenkelig å vektlegge dette, særlig hvis det er noe som ensidig kommer fra forvaltningen. Parten vil normalt innrette seg ved mottakelsen av vedtaket, og det vil dermed skape uforutsigbarhet om forvaltningen i ettertid kan påvirke vedtakets innhold. Vekten av dette hensynet beror imidlertid på om parten faktisk har innrettet seg før eller etter den aktuelle etterfølgende omstendighet og hva den faktiske innrettelsen bestod av. I rettspraksis har etterfølgende omstendigheter vært ansett relevant, men vekten av momentet varierer med typen omstendighet og graden av innrettelse.

En type etterfølgende omstendighet er at forvaltningen skriver en tolkningsuttalelse for å presisere innholdet av et vedtak. En slik uttalelse kan inneholde argumentasjon om tolkningen som i seg selv er overbevisende, men de hensyn som det er redegjort for ovenfor tilsier at det bør ha liten eller ingen vekt at forvaltningen mener noe er riktig tolkning. Når til og med en fast og konsistent forvaltningspraksis ofte vil ha liten vekt, tilsier det at en enkelt tolkningsuttalelse i hvert fall må ha liten vekt. I tillegg er det klart at forvaltningen - ved en tolkningsuttalelse ikke i realiteten kan endre et vedtak uten å følge de materielle vilkår og tidsfrister som følger av omgjøringsreglene i enten fvl. $§ 35$ eller annen forvaltningslovgivning.

En lignende etterfølgende omstendighet kan være vitneforklaringer fra personer i forvaltningen om hvordan vedtaket skal forstås eller hva som var ment. Selv om det ikke er et primært formål å finne ut hva forvaltningen har ment med vedtaket, kan forklaringer om dette likevel tenkes å påvirke tolkningen. Det at forklaringene er avgitt i ettertid og ikke var synbare på vedtakstidspunktet, tilsier imidlertid at vekten bør være lav. Vekten bør reduseres ytterligere dersom forklaringene avgis lang tid etter vedtaket, for eksempel under en rettssak.

Rt-1971-401 (Avkjøringstillatelse) gir et eksempel på vitneforklaringers relevans. Her hadde et selskap fått «tillatelse til å legge avkjørsel til bensinservicestasjon fra fylkesveg nr. 334 ved Pors stadion» (side 405). Som forklart ovenfor i punkt 5.2.1, holdt Høyesterett seg i hovedsak

\footnotetext{
${ }^{87}$ Boe (2010) s. 263.
} 
til ordlyden i vedtaket da det ble spørsmål om tillatelsen gjaldt både for bensinstasjon og kjøpesenter. Høyesterett fant likevel grunn til å omtale forklaringen fra førstesekretær Beck fra vegsjefens kontor:

«Uansett om partene måtte ha misforstått hverandre, eller der er erindringssvikt, så finner jeg det som nevnt klart at den tillatelse som er gitt, bare gjelder bensinservicestasjon. Becks forklaring viser at noe annet heller ikke har vart tilsiktet fra vegsjefens side.» (Side 404) (min kursivering).

Selv om forklaringen nok bare var et tilleggsargument til den klare ordlyden, var det likevel relevant.

En tredje type etterfølgende omstendighet er at forvaltningen fatter andre vedtak som står i sammenheng med tidligere vedtak. Det hender at disse andre vedtakene får betydning for tolkningen, slik at de blir lest i sammenheng.

Dette gir HR-2017-821-A (Marine Harvest) et eksempel på. Saken gjaldt straff for overtredelse av en forurensningstillatelse fra 1990. Ett av sakens spørsmål var om Marine Harvest i tillatelsen hadde fått en utslippsbegrensning eller en produksjonsbegrensning. En utslippsbegrensning ville kun begrenset hvor store utslipp selskapet kunne ha, og ikke hvor mye som kunne produseres. En produksjonsbegrensning ville derimot begrense produksjonen, selv om selskapet ikke skulle ha nådd et bestemt utslippsnivå. Med en utslippsbegrensning kunne altså selskapet produsere så mye det ville, så lenge det holdt seg innenfor utslippsgrensen. Høyesterett viste i avsnitt 29 til at det innledningsvis i vedtaket sto at selskapet hadde fått tillatelse til «produksjon av opp til 1000 000» (min kursivering) fisk. Deretter tok Høyesterett opp anførselen til Marine Harvest om at det senere i vilkårene stod at tillatelsen «gjeld for eit utslepp tilsvarende ein produksjon på opptil 1000 000» fisk (avsnitt 29). Det første tilsa en produksjonsbegrensning, mens det siste tilsa en utslippsbegrensning. Deretter kommer hovedpoenget i denne sammenheng:

«Formuleringene i vilkårene er ikke like klare, men ser man tillatelsen i sammenheng med 1993-vedtaket, er det etter mitt syn ingen tvil om at tillatelsen innebar en produksjonsbegrensning, ikke bare en utslippsbegrensning.» (Avsnitt 30.)

Høyesterett viste altså til et etterfølgende vedtak fra 1993 overfor samme selskap. 1993-vedtaket gjaldt en søknad om tillatelse til unntak fra 1990-vedtakets krav til at utslippene skulle legges på 30-meters dyp. Søknaden ble innvilget, men forvaltningen valgte også å presisere hvor mye som kunne produseres etter 1990-vedtaket - som forvaltningen uttalte at var en forutsetning i 1990-vedtaket. Høyesterett mente altså at 1993-vedtaket gjorde det klart hva som var 
innholdet av 1990-vedtaket. Denne etterfølgende omstendigheten synes dermed å ha blitt tillagt nærmest avgjørende vekt. Dette kan ved første øyekast virke betenkelig, men tiltalen gjaldt overtredelse i årene 2008-2012, og på dette tidspunktet hadde det gått lang tid siden selskapet måtte ha blitt klar over presiseringen i 1993-vedtaket. Det sistnevnte gjør dommen betydelig mindre betenkelig.

En fjerde type omstendighet er etterfølgende opptreden. Dette momentet kjenner vi fra avtaleretten, hvor man undersøker partenes opptreden etter avtaleinngåelsen for å se hva de mente med innholdet. Dersom den etterfølgende opptredenen kan kaste lys over en felles forståelse av et enkeltvedtak på vedtakstidspunktet, må dette kunne få betydning også her. Dette forutsetter at det er tale om den type enkeltvedtak hvor en felles tekstforståelse har betydning (se punkt 5.3 ovenfor). I slike situasjoner bør den etterfølgende opptredenen ha betydelig vekt om det er mulig å utlede noe av den. Når en felles tekstforståelse først anses for å være relevant, må alle omstendigheter som kaster lys over den være av interesse.

\subsection{Reelle hensyn}

\subsubsection{Kategorisering}

Ulike former for reelle hensyn kan gi relevante tolkningsmomenter. Norske domstoler synes å være opptatt av å finne løsninger de synes er rimelige eller gode når de tolker lover, avtaler og andre rettslige tekster. Det er ikke grunn til å tro at dette er eller bør være annerledes for enkeltvedtak.

Reelle hensyn kan kategoriseres i ulike grupper. Etter mitt syn er det mest hensiktsmessig å dele inn i formålsbetraktninger, konsekvensbetraktninger og rimelighetsbetraktninger. Denne begrepsbruken er inspirert av Eckhoffs begrepsbruk, men er ikke helt lik. ${ }^{88}$

\subsubsection{Formålsbetraktninger}

Med «formålsbetraktninger» sikter jeg til hensynet til de formål som kan utledes av vedtaket selv eller av andre tolkningsmomenter (som begrunnelsen, hjemmelsloven, forarbeidene og så videre). At noe har et formål vil si at det brukes som middel til å nå et bestemt mål. ${ }^{89}$ Vedtaket vil her være middelet som brukes til å nå et av forvaltningens mål, og det er denne målsetningen som kan være et tolkningsmoment.

\footnotetext{
${ }^{88}$ Eckhoff (2001) s. 382-393.

${ }^{89}$ Eckhoff (2001) s. 387.
} 
At domstolene vektlegger formålsbetraktninger illustreres av Rt-1972-32 (Ekspropriasjonstillatelse I). Som nevnt ovenfor, var spørsmålet om sjø- og elvegrunnen utenfor et landområde var omfattet av et ekspropriasjonsvedtak. En av anførslene til de private parter var at formålet med vedtaket var å skaffe tomtegrunn til boliger, hvilket skulle bety at det kun var land som ble omfattet av vedtaket. Høyesterett uttalte følgende om dette:

«Og jeg kan heller ikke se at det uttalte formål å skaffe tomtegrunn til boliger i seg selv på noen måte skulle tale imot den forståelse at ekspropriasjonen også skal omfatte sjøog elvegrunn. Ikke minst på Sørlandet, med den sterke interesse i strandområde til badeog båtplass, må det være nærliggende at et område for boligtomter også skal omfatte den tilstøtende strand med elve- og sjøgrunn.» (Side 37).

Høyesterett var altså uenig i den formålsbetraktning som ble anført, men vurderte likevel formålet og kom til at formålet heller trakk i motsatt retning.

I Rt-1957-375 (Konsesjonsvilkår) ble formålsbetraktninger anført som et vektig moment av førstvoterende (mindretallet i dette spørsmålet), mens flertallet tilla det mindre vekt. Som nevnt i punkt 5.2.2, gjaldt sakens andre hovedspørsmål om plikten etter konsesjonen til å holde sykehus og legehjelp i konsesjonstiden bare gjaldt for bedriftenes arbeidere eller om den også gjaldt arbeidernes familier, funksjonærene og funksjonærenes familier. Mindretallet bygde blant annet sin argumentasjon på formålsbetraktninger:

«Jeg legger her avgjørende vekt på det jeg før har sagt om at formålet med lovens bestemmelser - og da selvsagt også med bestemmelsene i konsesjonsvilkårene - var å skaffe lege og sykehusplass på steder hvor det før ikke var lege eller sykehus eller hvor det $\varnothing$ kede behov som industrianlegget skapte ikke var dekket. Det forekommer meg da lite naturlig å anta at det har vært meningen å holde funksjonærer og arbeidernes og funksjonærenes familier utenfor. Deres behov for lege og sykehus vil jo være akkurat det samme som når det gjelder arbeiderne.» (Side 379) (min kursivering).

Flertallet aksepterte at dette var relevante tolkningsmomenter ved å uttale at de «er oppmerksom[me] på de reelle hensyn som er nevnt av førstvoterende» (side 380), men flertallet la større vekt på at deres forståelse av vedtakets ordlyd pekte i motsatt retning (se punktene 5.2.2 og 5.2.3). Selv om flertallet kom til motsatt resultat, var altså formålsbetraktninger relevante.

Disse to dommene viser at formålsbetraktninger er relevante som tolkningsmomenter. Vekten av formålsbetraktninger vil variere med hvor sterkt de tilsier en bestemt tolkning og hva som ellers foreligger av tolkningsmomenter. 


\subsubsection{Konsekvensbetraktninger}

Med «konsekvensbetraktninger» sikter jeg til hensynet til samfunnsmessige virkninger. Ønskede virkninger vil støtte et tolkningsalternativ, mens uønskede virkninger vil tale imot et tolkningsalternativ. Hva som er ønskede virkninger vil kunne være politisk omstridt, men det hindrer ikke at domstolene av og til gjør konsekvensvurderinger og tillegger det vekt.

Konsekvensbetraktninger får en litt mindre rolle ved tolkning av enkeltvedtak enn det får ved tolkning av lover. Ved lovtolkning må man ha for øye at tolkningsresultatet vil gjelde for alle inntil Stortinget endrer loven. Ved tolkning av enkeltvedtak er det derimot kun tale om virkningene av at ett enkeltvedtak får et bestemt resultat. Riktignok kan det være andre enkeltvedtak som er utformet likt, men konsekvensene er likevel klart mindre. Det kan også være saker med betydelige beløp i spill, som i Rt-1985-1355 (Phillips Petroleum), men resultatet får sjelden stor betydning ut over den konkrete saken. Virkningene vil ha større likhetstrekk med avtaletolkning.

Jeg har ikke funnet noen høyesterettsdom som direkte omtaler slike virkninger. Grunnen til det er nok nettopp at det er sjelden vedtakene har store generelle virkninger.

I Rt-1976-562 (Skjenkebevilling) var konsekvensbetraktninger kanskje likevel et underliggende tema. Saken gjaldt straff for overtredelse av en skjenkebevilling. I bevillingen var det gitt tillatelse til skjenking av øl i «Fredriksten Kro’s lokaler i Festningen» (side 563). I forbindelse med en festival på et annet sted på festningsområdet, hadde kroen satt opp en utedisk. Spørsmålet var om denne skjenkingen var utenfor tillatelsens ordlyd om at skjenkingen måtte skje i deres «lokaler» i festningen. Høyesterett kom til at det forelå en overtredelse, og at en slik stedlig begrensning måtte innebære en forpliktelse til å sørge for at $\varnothing 1$ ikke ble tatt med vekk fra lokalene. En underliggende begrunnelse kan ha vært betydningen av om uttrykket «lokaler» skulle bli forstått uten denne stedlige begrensningen i alle skjenkebevillinger. Det ville gjort at mange allerede utstedte skjenkebevillinger ville fătt et mer omfattende innhold enn det som praktiseres, og gjort det nødvendig for forvaltningen å være betydelig mer presis i utformingen av senere vedtak.

Eksempelet tilsier i hvert fall at konsekvensbetraktninger kan bli vektlagt dersom det først foreligger noen virkninger utover betydningen saken har for partene. Også for dette momentet er det vanskelig å gi noen klare retningslinjer for vekten, annet enn at det vil variere med hva som foreligger av andre tolkningsmomenter. 


\subsubsection{Rimelighetsbetraktninger}

Med «rimelighetsbetraktninger» sikter jeg til hensynet til den konkrete rimeligheten overfor den private part og andre som eventuelt berøres av vedtaket. Et bestemt tolkningsresultat kan få stor betydning for de enkelte fysiske eller juridiske personer, og det er grunn til å tro at dette kan spille en rolle ved tolkningen av vedtakene. Dette står som motsetning til de generelle virkninger av en sak, som jeg ovenfor har kalt «konsekvensbetraktninger».

Forvaltningsorganets interesser er en del av de samfunnsmessige interesser eller lovens formål, og faller dermed utenfor det jeg her kaller «rimelighetsbetraktninger», men innenfor gruppene ovenfor.

Rt-1933-1012 (Larerlønn II) gir et eksempel på at konkret rimelighet ble trukket frem som argument i begge retninger ved tolkningen av et enkeltvedtak. Saken gjaldt tolkningen av et forbehold i Elverum kommunes lønnsregulativ. Når det gjelder spørsmålet om et slikt lønnsregulativ er et enkeltvedtak, viser jeg til drøftelsen av Rt-1930-1305 (Larerlфnn I) i punkt 4.3. ${ }^{90}$ I lønnsregulativet sto det at kommunen bare kunne nedregulere lønnen til lærerne «saafremt staten gaar til nedregulering av de for statsfunksjonærer nettop fastsatte lønninger» (side 1014). Etter at staten nedregulerte sine lønninger til lærere, nedregulerte kommunen lønnen mer enn staten hadde gjort. Spørsmålet var om forbeholdet også innebar at kommunen ikke kunne nedregulere mer enn staten gjorde.

Høyesterett henviste til overrettens dissenterende dommers begrunnelse. Denne dommeren la sterk vekt på ordlyden, og kom til at kommunen kunne nedregulere lønningene mer enn staten hadde gjort. Det interessante i denne sammenheng var at også konkrete rimelighetsbetraktninger var tema. På den ene siden kunne man anført at det ville vært rimelig å tolke forbeholdet slik at kommunen ikke kunne nedregulere lønnen mer enn staten, når reguleringskompetansen berodde på at staten nedregulerte lønnen først. Det ble derimot heller lagt en viss vekt på at «... folkeskolelærernes lønninger i Elverum i tiden 1914-1920 [var] forhøiet i langt sterkere grad enn statstjenestemennenes lønninger i samme tid, hvilket under et omslag kunde begrunne en sterkere nedsettelse» (side 1015).

Her viste Høyesterett uttrykkelig til at lærerlønningene i Elverum allerede var forhøyet i langt større grad enn for lærerne i staten, hvilket innebar at det ikke ville være så urimelig om deres lønn skulle nedreguleres mer enn statens lærere. Rimelighetsbetraktninger ble altså vektlagt.

\footnotetext{
${ }^{90}$ Castberg (1955) s. 152 synes å mene at akkurat denne dommen ikke gjelder tolkning av enkeltvedtak, men han påpeker uansett at saken gjelder et beslektet spørsmål og anvender den i argumentasjonen om tolkning av enkeltvedtak.
} 
Rimelighetsbetraktninger blir nok ofte vektlagt, både åpent og skjult, slik som ved tolkning av andre rettslig bindende tekster. Vekten beror på hvor sterkt rimelighetsbetraktningene tilsier en bestemt tolkning og hva som følger av andre tolkningsmomenter.

\subsection{Særskilte momenter ved tolkning av klagevedtak og omgjøringsvedtak}

\subsubsection{Innledning}

Fvl. § 28 gir rett til å klage på enkeltvedtak. I annen forvaltningslovgivning er det vanligvis tilsvarende klagerett. Etter klagebehandlingen vil klageorganet enten fatte eget vedtak i saken eller oppheve førsteinstansvedtaket og sende det tilbake til førsteinstansen for ny behandling, jfr. fvl. § 34 siste ledd. Dersom klageorganet fatter eget vedtak har parten fått et nytt enkeltvedtak å forholde seg til. Da er det dette vedtaket som gir uttrykk for partens rettigheter og plikter.

Forvaltningsloven og annen forvaltningslovgivning gir også en viss adgang til omgjøring av vedtak, se for eksempel fvl. § 35. Omgjøring er begrenset av både frister og materielle vilkår, men dersom forvaltningen holder seg innenfor begrensningene vil den kunne fatte nytt vedtak. Da er det dette vedtaket som gir uttrykk for partens rettigheter og plikter. Omgjøringsvedtak kan være aktuelt for både førsteinstansvedtak og klagevedtak.

Klagevedtak og omgjøringsvedtak vil på samme måte som et opprinnelig førsteinstansvedtak kunne reise tolkningsproblemer, og i utgangspunktet gjelder de samme tolkningsnormer. I tillegg kan det oppstå ytterligere tolkningsproblemer, som hva som er endret eller omgjort og hva det er endret eller omgjort til. Videre kan det foreligge ytterligere tolkningsmomenter. For klagevedtak vil det særlig være førsteinstansvedtaket og klagen. For omgjøringsvedtak vil det særlig være det opprinnelige vedtaket, en eventuell omgjøringsbegjæring og vilkårene for omgjøring. På grunn av ordbegrensningen for masteroppgaver må jeg nøye meg med noen korte synspunkter på dette.

\subsubsection{Klagevedtak}

\subsubsection{Betydningen av forsteinstansvedtaket}

Klagevedtaket kan enten gå ut på at klagen tas helt eller delvis til følge eller at den ikke tas til følge. I begge tilfeller vil førsteinstansvedtaket spille en rolle for tolkningen av vedtaket.

Dersom klages tas til følge, får førsteinstansvedtaket betydning på flere måter. For det første kan klagevedtaket da ikke gå ut på det samme som førsteinstansvedtaket. 
For det andre vil klagevedtaket eller begrunnelsen kunne ha henvisninger til førsteinstansvedtaket. Da er det klart at man må se på de deler av førsteinstansvedtaket som følger av ordlyden i klagevedtaket eller av begrunnelsen for klagevedtaket.

For det tredje vil klagevedtaket bygge på en gitt forståelse av førsteinstansvedtaket. Dette illustreres godt av klagevedtak fra Skatteklagenemnda, hvor det typisk kan stå følgende: «Klagen tas til følge. Skattegrunnlaget $\varnothing \mathrm{kes} /$ reduseres med x antall kroner». Hva skattegrunnlaget blir, vil da bero på det som er fastsatt i førsteinstansvedtaket pluss/minus det som følger av klagevedtaket. Det er i førsteinstansvedtaket vi kan se hva skattegrunnlaget opprinnelig var, og dermed hva det blir når vi legger til eller trekker fra det beløpet skattegrunnlaget skal $\varnothing$ kes eller reduseres med. Klagevedtaket bygger på denne forutsetningen. Tilsvarende informasjon kan vi ofte også få fra begrunnelsen, klagen og andre momenter, men disse bygger igjen på førsteinstansvedtaket.

Dersom klagen ikke tas til følge, vil det typisk bare stå at «klagen tas ikke til følge» eller lignende. Da vil det være førsteinstansvedtaket, altså førsteinstansens slutning, som gir uttrykk for rettighetene og pliktene til parten. Vedtakets begrunnelse vil imidlertid nå være klageinstansens begrunnelse, men også førsteinstansens begrunnelse kan ha betydning for tolkningen.

\subsubsection{Betydningen av klagen}

Ved tolkningen av klagevedtak har også klagen betydning. Klagens betydning minner om søknadens betydning for tolkningen av førsteinstansvedtak, og vil ha stor vekt.

Klagen setter en ramme for hva klageorganet tar stilling til og vedtar, og dette er synbart for den private part. Den private part kan ikke regne med at vedtaket går lenger enn klagen, selv om det er mulig. Dersom skattyter for eksempel klager over rettsanvendelsen på en av tre poster i skattevedtaket, kan han ikke regne med at klageorganet har endret innholdet $\mathrm{i}$ de to andre postene, hvis ikke det er klart presisert.

Samtidig gir klagen også synbare forutsetninger fra den private parts side, slik at dersom klageorganet ikke presiserer sitt vedtak (eller sin begrunnelse) tilstrekkelig, vil dette kunne gå utover forvaltningen.

Står det i klagevedtaket at «klagen tas til følge», er innholdet i klagen det helt sentrale for tolkningen. Uten nærmere presiseringer i vedtaket eller begrunnelsen, må man anta at klagen er tatt til følge i sin helhet. 
Hvis det ikke står direkte at «klagen tas til følge», men klageorganet likevel har endret førsteinstansvedtaket, må det undersøkes nærmere hva som har fått gjennomslag. Klagen er fortsatt viktig, men andre tolkningsmomenter vil da kunne få større betydning enn i tilfeller der «klagen tas til følge».

Dersom klagen avvises i sin helhet, spiller ikke klagen noen stor rolle for tolkningen. Riktignok vil det stå hva som er avslått, men rettighetene og pliktene følger av førsteinstansvedtaket.

\subsubsection{Omgjøringsvedtak}

På tilsvarende vis som førsteinstansvedtaket får betydning for tolkningen av klagevedtak, har det opprinnelige vedtaket betydning for tolkningen av omgjøringsvedtak. Omgjøringen kan på samme måte som klagen være hel eller delvis.

Dersom det foreligger en omgjøringsbegjæring vil dens betydning ligne på klagens betydning ved tolkning av klagevedtak. Omgjøring kan imidlertid også skje uten at det foreligger en begjæring hvis forvaltningen selv ønsker å endre vedtaket.

Videre vil hjemmelen for omgjøring og dens vilkår kunne ha betydning. Dersom omgjøringsvedtaket for eksempel bygger på fvl. $§ 35$ første bokstav a om endring som ikke er til skade, kan ikke omgjøringsvedtaket tolkes slik at parten kommer dårligere ut enn før. 


\section{$6 \quad$ Avsluttende observasjoner}

Siktemålet med oppgaven har vært å undersøke, analysere og redegjøre for hvordan de rettigheter og plikter som følger av et enkeltvedtak fastlegges. Etter mitt syn har jeg fått frem flere sentrale forhold ved tolkning av enkeltvedtak som ikke har vært behandlet tidligere.

Jeg har ikke kommet frem til noen overraskende resultater. Resultatene samsvarer i stor grad med det mange kunne tenke seg til uten nærmere undersøkelser. Mitt bidrag er at det for første gang har blitt gitt en grundig fremstilling av tolkning av enkeltvedtak, og da særlig av hvilke tolkningsmomenter som er relevante og deres vekt i avveiningen mot andre tolkningsmomenter.

Først viste oppgaven at det er vedtaksslutningen som er tolkningsobjektet ved tolkning av enkeltvedtak. Dette tilsvarer at domsslutningen er tolkningsobjektet ved tolkning av dommer.

Deretter ble det vist at domstolene har kompetanse til å tolke enkeltvedtak, både i rene fastsettelsess $\emptyset$ ksmål og i saker hvor tolkningen kommer opp prejudisielt. Det ble også vist hvordan tolkning av enkeltvedtak kan komme opp for domstolene på ulike måter.

Videre ble det vist at det ikke er ett enkelt tolkningsformål som preger domstolenes tolkning av enkeltvedtak. Selv om utgangspunktet er en objektiv tolkning av ordlyden i vedtaksslutningen, må også andre momenter av både objektiv og subjektiv karakter vurderes.

Selve tolkningen har likhetstrekk med tolkningen av andre rettslige tekster. Som ved tolkning av andre rettslige tekster er det også for enkeltvedtak tale om en avveining av en rekke tolkningsmomenter.

Tolkningsmomentene og deres vekt er også velkjente fra tolkning av andre rettslige tekster. Noen av momentene er velkjente fra all slik tolkning, andre er typiske ved enten lovtolkning, avtaletolkning eller tolkning av dommer. Analysen har vist at domstolene har en relativt pragmatisk holdning, og at de tar i bruk et bredt spekter av tolkningsmomenter etter behov.

Noen funn er spesielt interessante sammenlignet med lovtolkning og avtaletolkning. Ordlyden er selvsagt helt sentral også for tolkning av enkeltvedtak, men en viktig forskjell fra lovtolkning er at en felles tekstforståelse kan gå foran en objektiv forståelse av ordlyden. Dette er i samsvar med avtaletolkning. I motsetning til ved avtaletolkning, vil en felles tekstforståelse likevel ikke ha alltid betydning selv om den kan bevises, fordi tredjepersoner direkte kan berøres av vedtaket. 
Videre kan hjemmelsloven få særlig betydning ved tolkning av enkeltvedtak. For det første vil hjemmelsloven få betydning ved at ord og uttrykk i vedtaket ofte har samme betydning som tilsvarende ord og uttrykk i hjemmelsloven. For det andre vil hjemmelsloven sette grenser for vedtakets innhold.

Rettspraksis og juridisk teori har, som i avtaleretten, først og fremst betydning som kilde til hvilke tolkningsnormer som gjelder, fordi det er lite aktuelt at det for et konkret enkeltvedtak foreligger en dom med prejudikatsverdi eller en omtale i juridisk teori. Tolkning av enkeltvedtak skiller seg her fra lovtolkning, hvor rettspraksis og juridisk teori har betydning både som kilde til tolkningsnormer og som tolkningsmomenter.

Lovforarbeider har liten direkte betydning for tolkningen av enkeltvedtak. Vedtakene kan imidlertid ha egne forarbeider eller annen forhistorie som kan være relevante tolkningsmomenter.

I likhet med tolkning av lover og avtaler, har reelle hensyn også betydning ved tolkning av enkeltvedtak. Det er likevel forskjeller i hvilke typer hensyn som ofte får betydning, fordi lover gjelder mer generelt enn enkeltvedtak og avtaler. Ved lover vil de større konsekvensbetraktninger spille en stor rolle, mens konkret rimelighet er langt viktigere for enkeltvedtak og avtaler.

Avslutningsvis vil jeg påpeke at det er overraskende at tolkning av enkeltvedtak ikke er behandlet grundig tidligere. Temaet kan være praktisk viktig på mange ulike områder innenfor forvaltningsretten. Videre kan temaet ha betydning i strafferetten, fordi straff kan være aktuelt ved overtredelse av enkeltvedtak. Endelig mener jeg temaet er interessant fra en metodisk synsvinkel. 


\section{Kildeliste}

\section{Litteratur}

Aanerud (2017)

Aanerud, Jan Gudmund. «Tolkning av reguleringsplaner», Tidsskrift for eiendomsrett, volum 13, nr. 2 (2017), side 111172.

Andenæs (2016)

Andersen (1930)

Andersen, Poul. Hovedpunkter af forvaltningsretten I, København: Nyt nordisk forlag, 1930.

Backer (2015)

Backer, Inge Lorange. Norsk sivilprosess, Oslo: Universitetsforlaget, 2015.

Bernt (1981)

Bernt, Jan Fridthjof. Avtaler med stat og kommune, Bergen: Universitetsforlaget, 1981.

Bernt og Rasmussen (2010) Bernt, Jan Fridthjof og Ørnulf Rasmussen. Frihagens forvaltningsrett, 2. utgave, Bergen: Fagbokforlaget, 2010.

Boe (2010)

Boe, Erik Magnus. Innføring i juss. Juridisk tenkning og rettskildelaere, 3. utgave, Oslo: Universitetsforlaget, 2010.

Boe (2012)

Boe, Erik Magnus. Rettskildelaere under debatt, Oslo: Universitetsforlaget, 2012.

Boe og Woxholth (2013) Boe, Erik Magnus og Geir Woxholth. «Forvaltning eller kontrakt: Den ene, det annet, begge deler eller ingen av delene?», i Undring og erkjennelse. Festskrift til Jan Fridthjof Bernt 70 år, Karl Harald Søvig, Sigrid Eskeland Schütz og Ørnulf Rasmussen (red.), Bergen: Fagbokforlaget, 2013.

Castberg (1955)

Castberg, Frede. Innledning til forvaltningsretten, 3. utgave, Oslo: Akademisk forlag, 1955. 
Eckhoff (2001)

Eckhoff og Smith (2018)

Eng (1997)

Eng (2007)

Fleischer (1981)

Hagstrøm (2011)

Hopsnes (2017)

Huser (1983)

Høgberg (2006)

Høgberg (2007)

Høgberg (2012)

Innjord (2010)
Eckhoff, Torstein. Rettskildelare, 5. utgave ved Jan Helgesen, Oslo: Universitetsforlaget, 2001.

Eckhoff, Torstein og Eivind Smith. Forvaltningsrett, 11. utgave, Oslo: Universitetsforlaget, 2018.

Eng, Svein. «Får prejudikatlæren anvendelse på domsargumenter vedrørende rettskildelæren?», Tidsskrift for rettsvitenskap, årgang 110 (1997), side 22-44.

Eng, Svein. Rettsfilosofi, Oslo: Universitetsforlaget, 2007.

Fleischer, Carl August. Anvendelse og fortolkning av dommer, Oslo: Universitetsforlaget, 1981.

Hagstrøm, Viggo. Obligasjonsrett, 2. utgave, Oslo: Universitetsforlaget, 2011.

Hopsnes, Roald. Kommunale forhåndstilsagn. Adgangen til å forhåndsbinde forvaltningsmyndighet og rettsvirkningen av slik binding, Bergen: Fagbokforlaget, 2017.

Huser, Kristian. Avtaletolking. En innføring i avtaletolkingslaerens alminnelige del, Bergen: Universitetsforlaget, 2013.

Høgberg, Alf Petter. Kontraktstolkning. Sarlig om tolkningsstiler ved fortolkning av skriftlige kontrakter, Oslo: Universitetsforlaget, 2006.

Høgberg, Alf Petter. «I hvilken grad kommer rettsanvendelsestvil tiltalte til gode?», Jussens Venner, nr. 1 (2007), side 20-36.

Høgberg, Alf Petter. I språkets bilde, Oslo: Universitetsforlaget, 2012.

Innjord, Frode (red.). Plan- og bygningsloven med kommentarer, Oslo: Gyldendal akademisk, 2010. 
Knoph (1927)

Lødrup og Asland (2018)

Ruud og Ulfstein (2018)

Schei mfl. (2013)

Skoghøy (2017)

Skoghøy (2018)

Woxholth (2017)

Zimmer (2018)
Knoph, Ragnar. Betenkning av 16. september 1927 til advokat Herman Christiansen, Oslo: 1927.

Lødrup, Peder og John Asland. Arverett, 7. utgave, Oslo: Gyldendal akademisk, 2018.

Ruud, Morten og Geir Ulfstein. Innfфring i folkerett, 5. utgave, Oslo: Universitetsforlaget, 2018.

Schei, Tore, Arnfinn Bårdsen, Dag Bugge Nordén, Christian H. P. Reusch og Toril M. Øie. Tvisteloven. Kommentarutgave, 2. utgave, Oslo: Universitetsforlaget, 2013.

Skoghøy, Jens Edvin A., Tvisteløsning, 3. utgave, Oslo: Universitetsforlaget, 2017.

Skoghøy, Jens Edvin A., Rett og rettsanvendelse, Oslo: Universitetsforlaget, 2018.

Woxholth, Geir. Avtalerett, 10. utgave, Oslo: Gyldendal akademisk, 2017.

Zimmer, Frederik. Laerebok i skatterett, 8. utgave, Oslo: Universitetsforlaget, 2018.

\section{Lover og forskrifter}

1814 Grunnlov 17. mai 1814 Kongeriket Norges Grunnlov (Grunnloven).

1911 Lov 18. august 1911 nr. 9 om skatt for byene (byskatteloven) - opphevet.

1912 Lov 21. juni 1912 nr. 1 om veivæsenet (veiloven) - opphevet.

1920 Lov 3. desember 1920 nr. 2 om bygningsfredning (bygningsfredningsloven) - opphevet.

1924 Lov 22. februar 1924 nr. 2 om bygningsvesenet (bygningsloven) - opphevet. 
1967 Lov 10. februar 1967 om behandlingsmåten i forvaltningssaker (forvaltningsloven).

1972 Kongelig resolusjon av 8 desember 1972 om unders $\varnothing$ kelse etter og utnyttelse av undersjøiske petroleumsforekomster.

1981 Lov 13. mars $1981 \mathrm{nr} .6$ om vern mot forurensninger og avfall (forurensningsloven).

1981 Lov 22. mai 1981 nr. 25 om rettergangsmåten i straffesaker (straffeprosessloven).

1989 Lov 2. juni 1989 nr. 27 om omsetning av alkoholholdig drikk m.v. (alkoholloven).

2005 Lov 17. juni 2005 nr. 90 om mekling og rettergang i sivile tvister (tvisteloven).

2008 Lov 27. juni 2008 nr. 71 om planlegging og byggesaksbehandling (plan- og bygningsloven).

2008 Lov 15. mai 2008 nr. 35 om utlendingers adgang til riket og deres opphold her (utlendingsloven).

2016 Lov 27. mai 2016 nr. 14 om skatteforvaltning (skatteforvaltningsloven).

\section{Traktater}

EMK The European Convention on Human Rights, Roma 4. november 1950.

EØS-avtalen The Agreement on the European Economic Area, Porto 2. mai 1992.

\section{Forarbeider}

Ot.prp. nr. 51 (2004-2005) Om lov om mekling og rettergang i sivile tvister (tvisteloven).

Ot.prp. nr. 32 (2007-2008) Om lov om planlegging og byggesaksbehandling (plan- og bygningsloven) (plandelen). 


\section{Rettsavgjørelser}

Rettsavgjørelsene er først sortert tematisk, deretter etter instans. Den tematiske inndelingen er valgt for å lette tilgangen til kildematerialet som direkte gjelder tolkning av enkeltvedtak.

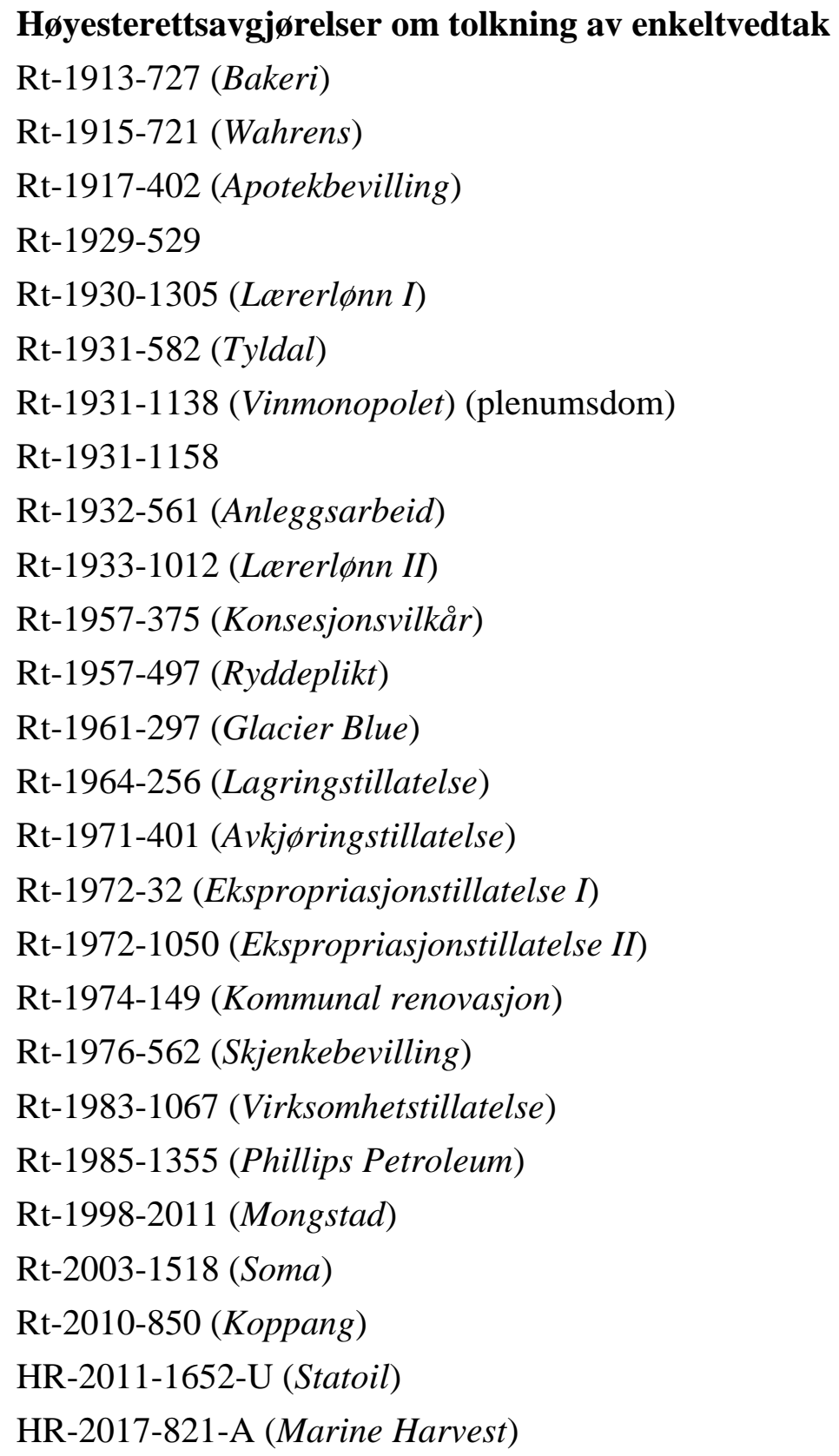

Lagmannsrettsavgjørelser om tolkning av enkeltvedtak

LB-2002-1303 (Fisketillatelse)

\section{Andre høyesterettsavgjørelser}

Rt-1929-771 (Oljepris) 
Rt-1984-91

Rt-1996-1480 (Reksten II)

Rt-2002-1155

Rt-2004-957 (PGS)

Rt-2012-18 (Kistefos)

Rt-2012-387 (Stedatter)

Rt-2014-1281

HR-2016-2017-A

HR-2017-1664-A

\section{Annen offentlig praksis}

\section{Uttalelser fra Sivilombudsmannen}

Sivilombudsmannen (2017). Spфrsmål om Riksantikvarens presisering av eksisterende fredningsvedtak er enkeltvedtak, 17. januar 2017 (sak 2015/3270 og sak 2015/3275 - felles uttalelse). https://www.sivilombudsmannen.no/uttalelser/sporsmal-om-riksantikvarens-presisering-av-eksisterende-fredningsvedtak-er-enkeltved$\underline{\text { tak/ }}$ [sitert 31. august 2018].

\section{Forvaltningspraksis}

Byrådet (2018). Søknad om serverings- og skjenkebevilling ved Odeon Oslo, 28. juni 2018 (sak 1068/Si18). https://www.oslo.kommune.no/dok/Byr/2018/BR2/2018035475-1919088.pdf [sitert 4. september 2018].

Grorud barneverntjeneste (2012). Melding om enkeltvedtak, 00.00.2012 (sak xyz.). Mottatt i anonymisert form per post fra Kommuneadvokaten i Oslo. Ikke tilgjengelig online. Kan vises ved forespørsel [sitert 28. august 2018].

Samferdselsdepartementet (2006). Konsesjon til Posten Norge AS, 18. desember 2006. https://www.regjeringen.no/globalassets/upload/kilde/sd/kon/2006/0001/ddd/pdfv/302146-postens_konsesjon.pdf [sitert 4. september 2018].

Skatteklagenemnda (2018). Nedsettelse av ligningsverdi for boligeiendom, 25. mai 2018 (sak 01 NS 77/2018). https://www.skatteetaten.no/rettskilder/type/vedtak/skatteklagenemnda/nedsettelse-av-ligningsverdi-for-boligeiendom/ [sitert 11. september 2018]. 


\section{Andre kilder: Nettsider, standardtillatelser og annet}

Olje- og energidepartementet. 2018. «Petroleumsloven og konsesjonssystemet». Lest 17. august 2018. https://www.norskpetroleum.no/rammeverk/rammeverkkonsesjonssystemet-petroleumsloven/

Olje- og energidepartementet. 2018. «Petroleumsloven og konsesjonssystemet», se «Standard utvinningstillatelse for nummererte runder» (link kan ikke vedlegges fordi vedlegget på nett er en word-fil, og ikke pdf-fil). Lest 17. august 2018. [sitert 3. september 2018].

Oslo kommune. Diverse årstall. Ulike anonymiserte enkeltvedtak mottatt i papirform fra Kommuneadvokaten i Oslo. Ikke tilgjengelig online. Kan vises ved forespørsel. Lest 20.-22. august 2018.

Oslo kommune. 2018. «DocuLive». Lest 3. september 2018. https://www.oslo.kommune.no/sru/default.asp

Oslo kommune. 2018. «Planinnsyn». Lest 17. august 2018. https://od2.pbe.oslo.kom$\underline{\text { mune.no/kart/\#598757,6643771,7 }}$

Regjeringen. 2018. «Anbud, konsesjoner og brev». Lest 30. august 2018. https://www.regjeringen.no/no/dokument/andre/id438824/

Skatteetaten. 2018. «Skatteklagenemnda». Lest 17. august 2018. https://www.skatteetaten.no/rettskilder/type/vedtak/skatteklagenemnda/ 